\title{
Machine learning for intraoperative prediction of viability in ischemic small intestine
}

\author{
Runar J Strand-Amundsen ${ }^{1,2}$, Christian Tronstad ${ }^{1}$, Henrik M. Reims ${ }^{3}$, Finn P. Reinholt ${ }^{3}$, Jan O \\ Høgetveit $^{1,2}$, and Tor I Tønnessen ${ }^{4,5}$ \\ ${ }^{1}$ Department of Clinical and Biomedical Engineering, Oslo University Hospital - Rikshospitalet, Postboks 4950 Nydalen, 0424 Oslo, \\ Norway \\ ${ }^{2}$ Department of Physics, University of Oslo, Postboks 1048 Blindern, 0316 Oslo \\ ${ }^{3}$ Department of Pathology, Oslo University Hospital - Rikshospitalet, Postboks 4950 Nydalen, 0424 Oslo, Norway \\ ${ }^{4}$ Department of Emergencies and Critical Care, Oslo University Hospital - Rikshospitalet, Sognsvannsveien 27, 0424 Oslo, Norway. \\ ${ }^{5}$ Institute of Clinical Medicine, University of Oslo - Rikshospitalet, Sognsvannsveien 20, 0424 Oslo, Norway.
}

E-mail: runar.strand-amundsen@fys.uio.no

Keywords: Intestinal viability, bioimpedance, recurring neural networks, LSTM, ischemia

\begin{abstract}
Objective: Evaluation of intestinal viability is essential in surgical decision-making in patients with acute intestinal ischemia. There has been no substantial change in the mortality rate (30-93\%) of patients with acute mesenteric ischemia (AMI) since the 1980's. As the accuracy from the first laparotomy alone is $50 \%$, the gold standard is a second-look laparotomy, increasing the accuracy to $87-89 \%$. This study investigates the use of machine learning to classify intestinal viability and histological grading in pig jejunum, based on multivariate time-series of bioimpedance sensor data. Approach: We have previously used a bioimpedance sensor system to acquire electrical parameters from perfused, ischemic and reperfused pig jejunum $(7+15$ pigs $)$ over 1-16 hours of ischemia and 1-8 hours of reperfusion following selected durations of ischemia. In this study we compare the accuracy of using endpoint bioimpedance measurements with a feedforward neural network (FNN), versus the accuracy when using a recurrent neural network with long short-term memory units (LSTM-RNN) with bioimpedance data history over different periods of time. Main results: Accuracies in the range of what has been reported clinically can be achieved using FNN's on a single bioimpedance measurement, and higher accuracies can be achieved when employing LSTM-RNN on a sequence of data history. Significance: Intraoperative bioimpedance measurements on intestine of suspect viability combined with machine learning can increase the accuracy of intraoperative assessment of intestinal viability. Increased accuracy in intraoperative assessment of intestinal viability has the potential to reduce the high mortality and morbidity rate of the patients.
\end{abstract}




\section{Introduction}

While evaluation of intestinal viability is essential in surgical decision-making in patients with acute intestinal ischemia (Tilsed et al., 2016; Horgan and Gorey, 1992), the standard intraoperative method of visual inspection and palpation is not very specific and requires a high level of clinical experience (Urbanavicius et al., 2011; Wyers, 2010). For clinical estimation of bowel viability, an overall accuracy of $89 \%$ (positive predictive value $64 \%$ ), including unnecessary bowel resection in $46 \%$ of the cases has been reported (Bulkley et al., 1981). Redaelli et al. reported an accuracy of $87 \%$ and a positive predictive value of $69 \%$ when including the second look evaluation. From the first laparotomy alone only 50\% of the non-viable cases were correctly identified (Redaelli et al., 1998). Leaving non-viable intestine can lead to sepsis (Kudszus et al., 2010; Herbert and Steele, 2007), while extensive resection of bowel can lead to short-bowel syndrome (Seetharam and Rodrigues, 2011). Bowel ischemia is associated with a mortality rate in the range of 30-93\% (Tilsed et al., 2016; Bala et al., 2017; Brandt and Boley, 2000). There has been no substantial change in the mortality rate of patients with acute mesenteric ischemia since the 1980's (Meng et al., 2010).

Many experimental approaches have been taken with the aim of providing the surgeon with methods to increase the accuracy of viability assessment, but few methods have proven applicable (Urbanavicius et al., 2011). One suggested approach not extensively investigated, is the use of electrical tissue properties to assess intestinal viability (Matsuo et al., 2004; Beltran and Sacristan, 2015; Gonzalez et al., 2003; Carey et al., 1964).

We have previously used a model of segmental mesenteric occlusion on pig jejunum, to delineate how the electrical parameters of the in-vivo small intestine change during full mesenteric ischemia (Strand-Amundsen et al., 2016) and reperfusion (Strand-Amundsen et al., 2018b). Placing electrodes on opposing sides of the intestine and measuring trans-intestinal electrical parameters, we found that the time course of the ratio parameter $\tan \delta$ (loss tangent/dissipation factor) had significant associations with the intestinal tissue state (control, ischemia, reperfusion). The parameters $\operatorname{Tan} \delta m$ (max $\tan \delta$ amplitude over a frequency range) and $\operatorname{Tan} \delta m F$ (the frequency where $\tan \delta$ m occurs) followed a characteristic time-course dependent on the duration of ischemia and/or reperfusion as well as exposure to pre-reperfusion ischemia. As the time-course of the electrical parameters measured on pig jejunum during ischemia/reperfusion are non-linear, frequency dependent and complex, we have in the present paper investigated classification tools that may assist in analysing longitudinal multivariate bioimpedance data.

Over the past few years, methods for classification learning have been increasingly available by software packages, libraries and by the processing power of modern consumer computers able to run simple machine learning tasks quickly. Many of the popular classification learning algorithms are well suited for capturing non-linear relations between many input features and a target, such as artificial neural networks (ANN). With respect to bioimpedance measurements (usually providing several immittance parameters over multiple frequencies), recurrent neural networks (RNN) are of interest because of the possibility of learning patterns in multivariate timeseries during events such as ischemia and reperfusion. One particular type of RNN, introduced by Hochreiter and Schmidhuber in 1997, which over the last few years has proven very successful for learning time-series patterns, is deep RNN with long short-term memory (LSTM) units (Hochreiter and Schmidhuber, 1997).

This network is especially well suited for classifying sequence data (repeated observations with multiple features) (Jurtz et al., 2017), and has demonstrated superior performance in applications such as language interpretation (Gers and Schmidhuber, 2001), sentiment classification (Wang et al., 2016), sound event detection (Adavanne et al., 2016), human action recognition (Liu et al., 2016) and handwriting recognition (Yousefi et al., 2015). This type of network is suitable for multimodal wearable sensors, can perform sensor fusion naturally, does not require expert knowledge in designing features and explicitly models the temporal dynamics of feature activations (Ordonez and Roggen, 2016).

In the present paper we have investigated the use of shallow and deep learning to classify intestinal viability and histological grading in pig jejunum, based on complex bioimpedance data from a previous experiment series (Strand-Amundsen et al., 2018b). We compared the accuracy of using end-point measurements with a feedforward neural network (FNN), versus the accuracy when using a recurrent neural network with LSTM units (LSTM-RNN) using data history over different periods of time. We used the viability assessment and histological grading made 
by pathologists (HMR/FPR) on jejunal tissue samples from the previous experiment series as a reference. We previously found that probable irreversible damage occurred in pig jejunum that had been mesenteric occluded for $\geq 4$ hours followed by reperfusion (total loss of crypt epithelium, extensive shrinkage and loss of myocytes in the outer layer of the muscularis propria) (Strand-Amundsen et al., 2018a). The overall aim of this project is to develop a tool for the surgeon to allow for more accurate intraoperative assessment of intestinal viability, than presently possible. The effect of a higher accuracy is a potential reduction in the need for second look surgery and in the frequency of post-operative sepsis or short bowel syndrome.

\section{Methods}

\subsection{Animals and experimental design}

The data analysed in the present study was collected in a previous study with 15 Norwegian Landrace pigs, weight range 44.3-58.6 kg, 11 females (Strand-Amundsen et al., 2018b). To investigate the viability limit of the jejunum we created series of segments, with intervals of ischemia ranging from 1-16 hours, and segments with reperfusion (8-15 hours) initiated after 1-8 hours of ischemia. Multiple segments were created in the same pig (Chan et al., 1998). Local ischemia was induced by clamping the arteries and veins (30 cm segments) of the jejunal mesentery, resulting in a $20 \mathrm{~cm}$ central zone of warm ischemia and two surrounding $5 \mathrm{~cm}$ edge zones of marginal tissue hypoxia (Noer and Derr, 1949). More than $30 \mathrm{~cm}$ intervals were used between the selected segments. Reperfusion was initiated by releasing the clamps and verified by observing the return of colour in the previously ischemic segments. Control segments were selected on perfused jejunum in the same pig. The protocol was designed to minimize pain or discomfort to the animals and reduce the overall number of animals used. The experiment was approved by the Norwegian Food Safety Authority and conducted in accordance with national animal welfare guidelines and directive 86/609/EEC.

\subsection{Bioimpedance measurements}

The bioimpedance measurements were performed by a Solartron ${ }^{\circledR} 1260$ Impedance/gain-phase analyser (Solartron Analytical, United Kingdom) with a 1294A interface. The Solartron was controlled, data logged, and measurements acquired by the Zplot ${ }^{\circledR}$ software (Copyright $(0)$ 1990-2015 Scribner Associates, USA). A 2-electrode setup (each electrode acting both as stimulating and pickup electrode), with $9 \mathrm{~mm}$ diameter Quickels® (Quickels System $\mathrm{AB}$, Sweden) $\mathrm{Ag} / \mathrm{AgCl}$ electrocardiography disc electrodes (intrinsic $R=0.18 \mathrm{ohm}, X=0 \mathrm{ohm}$ ), was used for the measurements. During measurement, the intestinal area under investigation was placed between the two opposing electrodes with a light pressure to exclude air between the intestinal surface and the electrodes. The sensor system is shown in figure. 1. 


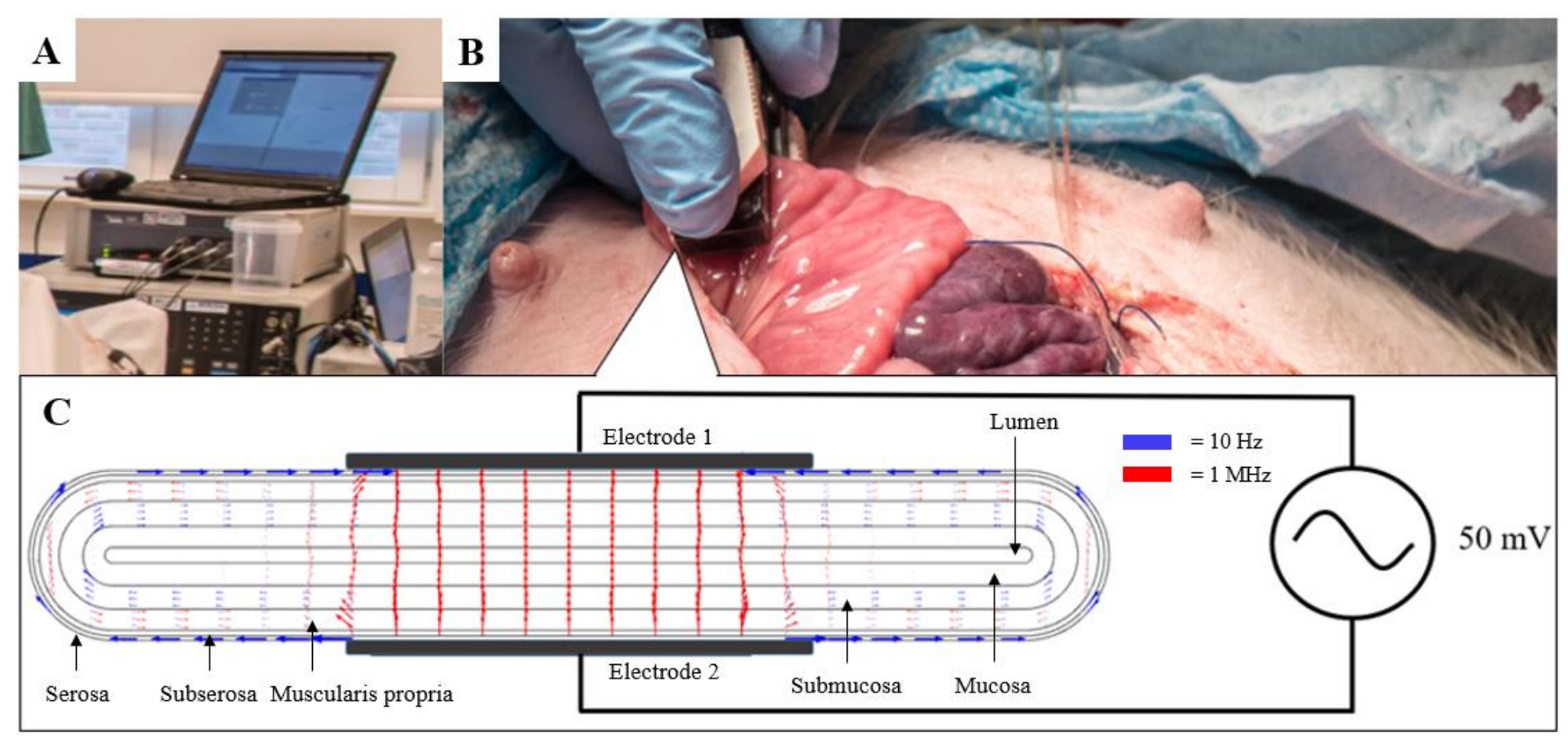

Figure. 1. A) Solartron ${ }^{\circledR} 1260$ Impedance/gain-phase analyzer (Solartron Analytical, United Kingdom) with a 1294A interface. B) The small intestine placed between a set of Quickels® (Quickels System AB, Sweden) Ag/AgCl electrocardiography disc electrodes. C) A comparison of the arrow surface plot of the current density (proportional) distribution in a cross section of the layers of the small intestine, at two frequencies, created by finite element modelling of a transintestinal measurement at $10 \mathrm{~Hz}$ (blue) and $1 \mathrm{M} \mathrm{Hz}$ (red) in COMSOL Multiphysics 5.1 (Comsol Group, Sweden). The parameters used for modelling the various layers of the small intestine are based on the tissue data from the Italian national research council/Institute for applied physics/IFAC-CNR (Andreuccetti et al. 1997).

A 50mV AC RMS signal was applied across the electrodes while sweeping the frequencies from $1 \mathrm{~Hz}$ to $1 \mathrm{MHz}$. Measurements were made hourly, and each measurement lasted 1.5 minutes. The resulting current was measured, and the impedance calculated. Using the in-phase resistance $(R)$ and the capacitive reactance $(X)$ of the impedance, we calculated the loss tangent $\tan \delta$ (Surowiec and Stuchly, 1986). Tan $\delta$ is the unitless frequency dependent ratio between the $R$ and $X$. Increasing $\tan \delta$ indicates that electrical power is consumed at increasing rate.

$$
\operatorname{Tan} \delta=\frac{R}{X} \quad[\text { Unitless }]
$$

$R=$ Real part of the impedance, resistance

$X=$ Imaginary part of the impedance, reactance

Tan $\delta=$ Loss tangent/dissipation factor

$\operatorname{Tan} \delta m=$ maximum $\tan \delta$ amplitude over a frequency range

$\operatorname{Tan} \delta m F=$ frequency where $\operatorname{Tan} \delta \mathrm{m}$ occurs

Using $9 \mathrm{~mm}$ diameter $\left(\right.$ area $\left.=63.6 \mathrm{~mm}^{2}\right)$ non-polarizable $\mathrm{Ag} / \mathrm{AgCl}$ electrodes resulted in very low electrode polarization impedance, that started to dominate gradually below $100 \mathrm{~Hz}$. Over time, there was a small variation in the electrical parameters of the control tissue (Strand-Amundsen et al., 2018a; Strand-Amundsen et al., 2016), and this was estimated to be mainly due to irritation in the intestinal tissue caused by handling and proximity to the ischemic tissue.

\subsection{Histology}

In the previous experiment (Strand-Amundsen et al., 2018b), we collected intestinal tissue samples for light microscopy at selected time intervals from control jejunum, ischemic jejunum and reperfused jejunum. The biopsies 
were fixed overnight in buffered formalin, embedded in paraffin wax, sectioned and stained as described (StrandAmundsen et al. 2018). The sections were evaluated by light microscopy by two pathologists (HMR \& FPR) and the viability of the tissue sample was estimated. The histological damage was also graded using Park/Chiu (Park et al., 1990; Chiu et al., 1970) and a modification of the Swerdlow grading (Plonka et al., 1989; Hegde et al., 1998; Swerdlow et al., 1981). In addition, 58 samples at selected time intervals from 3 pigs were collected and fixed in a phosphate-buffered mixture of glutaraldehyde and paraformaldehyde, embedded in an epoxy resin, and ultra-thin sections were examined by transmission electron microscopy (TEM) by one pathologist (FPR) as described (StrandAmundsen et al. 2018). The focus was on estimating tissue viability in the muscularis propria.

\subsection{Dataset and pre-processing}

The dataset consisted of 1164 observations of $\tan \delta$ spectra from 15 pigs, with repeated bioimpedance measurements hourly over a duration ranging from 3 to 16 hours, giving a total of 120 data sequences. The sequences were labelled according to the maximum histological damage grading during the course of the experiment. Three different labels were used: The Swerdlow class maximum score, the Park-Chiu class maximum score, and a binary class representing reversible or irreversible tissue damage based on whether the Swerdlow class reached a score of 6 (indicating transmural infarction). From the 120 sequences, 79 long sequences (having a length of at least 10h) were selected for classification based on measurement history including both ischemia and reperfusion. For classification assessment based on only the reperfusion part of the experimental data, all sequences with at least $5 \mathrm{~h}$ of reperfusion were selected, giving a total of 64 sequences. Although the Swerdlow and Park-Chiu scores have 6 and 8 possible levels respectively, only four levels for Swerdlow $(0,2,5,6)$ and Park-Chiu $(0,5,7,8)$ were available in the data as reference points of the tissue state in the analysed datasets. For the long sequences, the distribution of labels was $52 \%$ vs $48 \%$ for reversible vs irreversible damage, and $19 \%, 19 \%, 14 \%$ and $48 \%$ for the four damage grading levels. For the reperfusion sequences, this distribution was $64 \%$ vs $36 \%$ for reversible vs irreversible damage, and $23 \%$, $23 \%, 17 \%$ and $36 \%$ for the four damage grading levels.

Each sequence had a feature set of Tan $\delta$ over different frequencies $(60$ frequencies between $1 \mathrm{~Hz}$ and $1 \mathrm{MHz}$, $\log$ distributed), the Tan $\delta m$ and the Tan $\delta m F$. The only pre-processing applied to the data was dividing the Tan $\delta m F$ by 1000 in order to keep all feature variables at a comparable scale. Prediction of tissue viability was assessed for different data points and segments, based on an estimation of clinical application and relevance of the method (for details see figure 2).

Prediction using only reperfusion measurements simulates a more clinically relevant case where the first measurement corresponds to where the abdomen is opened and right before reperfusion is initiated. Since the changes in electrical parameters in the tissue after the initiation of reperfusion are gradual, we chose the initial measurement taken right before the initiation of reperfusion to represent the starting point of reperfusion. Figure 2 illustrates the dataset and the different predictions assessed. Classification using all or clinically relevant intervals of history of repeated measurements with different labels (binary as reversible/irreversible injury, the Swerdlow scale and the Park-Chiu scale) was compared to classification using single measurement points at selected intervals, employing suitable machine learning approaches for both cases. 


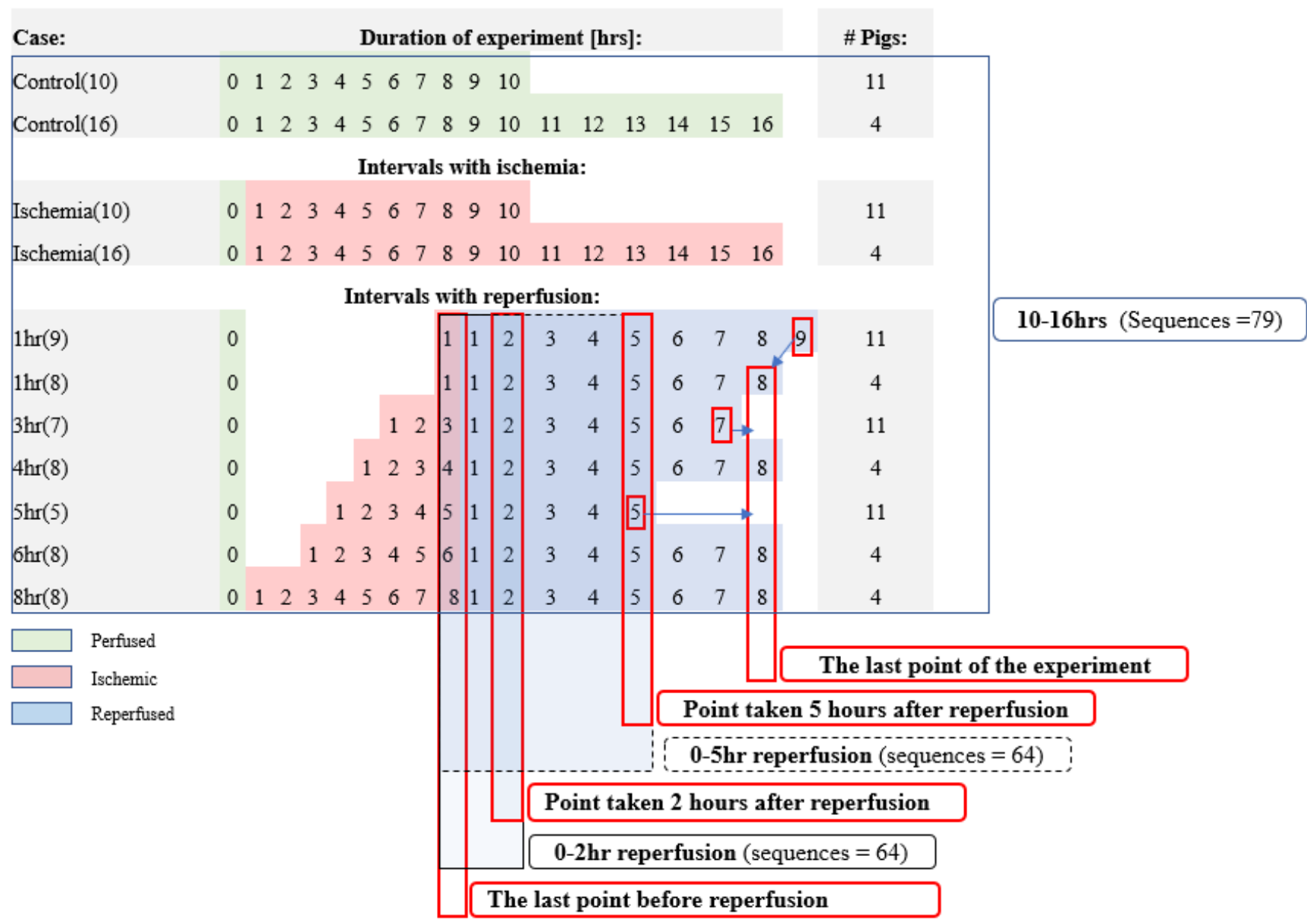

Figure. 2. Overview of data used for assessment of predicting viability based on different measurement points or sequences of repeated measurement. All sequences with duration of 10 hours or more (including both ischemia and reperfusion) were used for classification based on the total experimental length. For more clinically relevant cases, the first measurement point before reperfusion (simulating a measurement at the opening of the abdomen), the measurement points gathered at $2 \mathrm{~h}$ and $5 \mathrm{~h}$ of reperfusion and the measurement history from $0-2 \mathrm{hours}$ and $0-5$ hours of reperfusion, were also assessed for performance in prediction of tissue viability. The last measurement points of these intervals were used to compare classification using the whole sequence of repeated measurements versus classification using only single measurement points.

\subsection{Machine learning for classification}

Two types of artificial neural networks were used to train classification models for prediction of tissue viability.

For classification based on a point measurement, a feed forward neural network (FNN) with one hidden layer of tan-sigmoid nodes and a softmax output layer was employed. For the case using segments of repeated measurement, a deep recurrent neural network (RNN) was used for classification learning of the multivariate time-series, composed of a sequence input layer, an LSTM layer, a fully connected layer, a softmax layer and a classification layer. For learning with reduced bias from hyperparameter tuning, repeated double cross-validation (RDCV) (also called nested cross-validation) was applied, with selection of the hyperparameter set within an inner 5-fold CV loop, and prediction in an outer 5-fold CV loop. By this method, models with all hyperparameter combinations are trained in 5 folds within the inner loop, and for each fold validated against the inner validation partition. Based on the accuracies (percentage of correct classes predicted) on the validation partitions for each hyperparameter combination, the hyperparameter set to be used for prediction on the outer test folds was selected. The initial hyperparameter set shown in table 1 was used as a basis for grid-search on the inner CV loop (only the regularization, layer size and feature set hyperparameters were used for the FNN). Classification performance was assessed for binary classification (reversible or irreversible damage), the Park-Chiu score (four classes) and the 
Swerdlow score (four classes), calculated as the mean percentage of correct class predictions in the test sets over 10 RDCV runs, with the standard deviation over the runs also provided.

Table 1. Hyperparameter list used for grind search in model development ${ }^{1}$.

\begin{tabular}{lcl}
\hline Hyperparameter & Number of choices & Values \\
\hline Number of & 2 & 500,1000 \\
Epochs & 3 & $0.001,0.01,0.1$ \\
L2 regularization & 3 & $16,32,64$ \\
Mini-batch Size & 5 & $2,5,10,30,100$ \\
Layer size & 3 & {$[$ TanDmax, freq_TanDmax], [TanD(63kHz), } \\
Feature set & TanD(6,3kHz), TanD(500Hz), TanDmax, \\
& freq_TanDmax], [All TanD(frequency range), \\
& TanDmax, freq_TanDmax] \\
& \multicolumn{3}{l}{ Number of epochs and mini-batch size were } & not applicable in training the feed forward neural network
\end{tabular}

Additional options in training the RNN was the initial learning rate, the learning rate drop factor and learning rate drop period, which was set to 1.0, 0.9 and 10 respectively based only on speed and stability of the training error convergence before the RDCV was run. Within each of the inner CV folds, models were trained for all hyperparameter combinations, and the combination giving highest mean accuracy over the inner validation folds was chosen as the optimal hyperparameter set for the current run and outer fold. In the outer CV loop, predictions were made for all hyperparameter combinations and stored until the nested CV had run 10 times with different random permutations of the dataset.

After all runs, the final hyperparameter set was determined by finding the most frequent optimal hyperparameter set over all runs and outer fold iterations. The final prediction performance was determined by extracting the outer loop predictions belonging to this final hyperparameter set and calculating its mean and standard deviation over all runs and outer folds. In the event of more than one optimal hyperparameter set having maximum count over the runs and folds, the set of hyperparameters among these representing the lowest model complexity (size of feature set and layer size) was selected.

The RDCV implementation was similar to the method as introduced by Filzmoser et al., but with hyperparameter grid search instead of one-dimensional optimization of model complexity as in the original paper (Filzmoser et al., 2009). Selection of criteria for hyperparameter search was done based on the recommendations made by Bengio (Bengio, 2012). For implementation in software, the Neural Network Toolbox in Matlab 2017b (Mathworks, Natick, Massachusetts, United States) was employed, using the trainNetwork() function for training the LSTM-RNN and the train() function for the FNN.

\section{Results}

The classification performance of all cases that were assessed are presented in table 2 and figure 3 . The highest mean accuracies (binary 95.7\%, Swerdlow 91.3\%, Park/Chiu 89.0\%) were achieved using LSTM-RNN on the measurements from the total experiment including both ischemia and reperfusion phases. 5 hours of reperfusion history also resulted in a very high mean accuracy (binary 92.4\%, Swerdlow 93.0\% Park/Chiu 87.5\%). Using the data point just before the initiation of reperfusion yielded the highest accuracy when classifying single measurement points (binary $91.5 \%$, Swerdlow 72.5\%, Park/Chiu 70.8\%). 


\section{Classification of intestinal viability and histological grading}

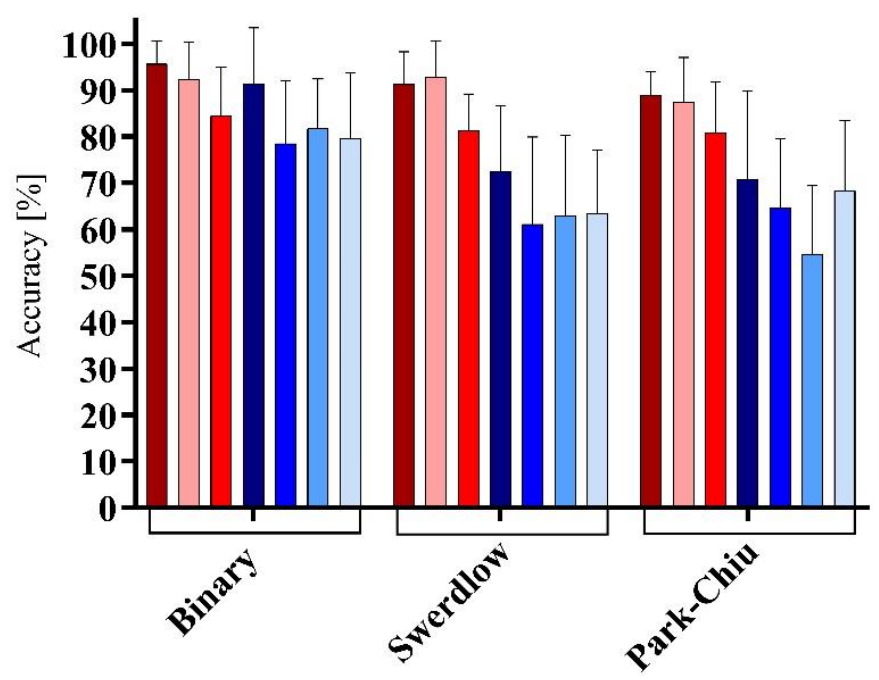

- Total history (ischemia+reperfusion) (LSTM)

$\square \quad 5$ hours of reperfusion history (LSTM)

- 2 hours of reperfusion history (LSTM)

- Last point before reperfusion (FNN)

- Point taken $2 \mathrm{~h}$ after reperfusion (FNN)

$\square \quad$ Point taken $5 \mathrm{~h}$ after reperfusion (FNN)

$\square \quad$ Last point of experiment (FNN)

Figure. 3. Classification of intestinal viability (binary) and histological grading using LSTM-RNN and FNN. Mean accuracy with SD are shown as bars with error bar on top. For "Total history", "Last point before reperfusion" and "Last point of experiment" $n=79$, for the rest $\mathrm{n}=64$.

No particular hyperparameter set stood out as consistent between the different set of classes and sequences, neither for the RNN nor the FNN models. The most consistent selections were a larger layer size (30 or 100 nodes), and either five or all tanD variables as features. For most of the RNN cases, the final set was either with 100 nodes and 5 feature variables, or with 30 nodes and all $\mathrm{N}$ features variables. The FNN set was less consistent between cases, with the layer size being mostly 5 or 10 nodes, and the feature set being mostly two or five tanD variables.

Table 2. Viability prediction performance results for the different sequences/points and for the different classification scales ${ }^{1}$.

\begin{tabular}{|c|c|c|c|c|c|c|}
\hline Sequence data & Classes & $\begin{array}{l}\text { Network } \\
\text { type }\end{array}$ & $\begin{array}{c}\text { Mean } \\
\text { accuracy } \\
{[\%]}\end{array}$ & $\begin{array}{c}\text { Std. dev } \\
{[\%]}\end{array}$ & $\begin{array}{l}\text { Number of } \\
\text { sequences }\end{array}$ & $\begin{array}{c}\text { Hyperparameters } \\
\text { (number according } \\
\text { to table 1) }\end{array}$ \\
\hline Total (ischemia+reperfusion) & Binary & LSTM & 95.7 & 5.0 & 79 & {$\left[\begin{array}{llllllll}2 & 3 & 3 & 4 & 1\end{array}\right]$} \\
\hline Total (ischemia+reperfusion) & Swerdlow & LSTM & 91.3 & 7.0 & 79 & {$\left[\begin{array}{lllll}2 & 2 & 1 & 5 & 2\end{array}\right]$} \\
\hline Total (ischemia+reperfusion) & $\begin{array}{l}\text { Park- } \\
\text { Chiu }\end{array}$ & LSTM & 89.0 & 5.0 & 79 & {$[2,2,1,5,2]$} \\
\hline Last point of experiment & Binary & FNN & 79.6 & 14.1 & 79 & {$\left[\begin{array}{lll}1 & 1 & 3\end{array}\right]$} \\
\hline Last point of experiment & Swerdlow & FNN & 66.6 & 19.7 & 79 & {$\left[\begin{array}{lll}1 & 2 & 2\end{array}\right]$} \\
\hline Last point of experiment & $\begin{array}{l}\text { Park- } \\
\text { Chiu }\end{array}$ & FNN & 68.5 & 15.1 & 79 & {$\left[\begin{array}{lll}2 & 3 & 3\end{array}\right]$} \\
\hline Last point before reperfusion & Binary & FNN & 91.5 & 12.0 & 79 & {$\left[\begin{array}{lll}2 & 1 & 3\end{array}\right]$} \\
\hline Last point before reperfusion & Swerdlow & FNN & 72.5 & 14.2 & 79 & {$\left[\begin{array}{lll}1 & 3 & 1\end{array}\right]$} \\
\hline Last point before reperfusion & $\begin{array}{l}\text { Park- } \\
\text { Chiu }\end{array}$ & FNN & 70.8 & 19.0 & 79 & {$\left[\begin{array}{lll}2 & 2 & 3\end{array}\right]$} \\
\hline At $2 \mathrm{~h}$ after reperfusion & Binary & FNN & 78.5 & 13.6 & 64 & {$\left[\begin{array}{lll}3 & 3 & 3\end{array}\right]$} \\
\hline At $2 \mathrm{~h}$ after reperfusion & Swerdlow & FNN & 61.1 & 18.8 & 64 & {$\left[\begin{array}{lll}3 & 3 & 2\end{array}\right]$} \\
\hline
\end{tabular}




\begin{tabular}{|c|c|c|c|c|c|c|}
\hline At $2 \mathrm{~h}$ after reperfusion & $\begin{array}{l}\text { Park- } \\
\text { Chiu }\end{array}$ & FNN & 64.6 & 15.0 & 64 & {$\left[\begin{array}{lll}3 & 3 & 2\end{array}\right]$} \\
\hline 2 hours of reperfusion & Binary & LSTM & 84.6 & 10.4 & 64 & {$\left[\begin{array}{lllll}2 & 3 & 1 & 2 & 1\end{array}\right]$} \\
\hline 2 hours of reperfusion & Swerdlow & LSTM & 81.3 & 7.9 & 64 & {$\left[\begin{array}{lllll}1 & 3 & 1 & 4 & 1\end{array}\right]$} \\
\hline 2 hours of reperfusion & $\begin{array}{l}\text { Park- } \\
\text { Chiu }\end{array}$ & LSTM & 80.8 & 10.9 & 64 & {$\left[\begin{array}{lllll}1 & 3 & 3 & 4 & 1\end{array}\right]$} \\
\hline At $5 \mathrm{~h}$ after reperfusion & Binary & FNN & 81.8 & 10.6 & 64 & {$\left[\begin{array}{lll}2 & 2 & 3\end{array}\right]$} \\
\hline At $5 \mathrm{~h}$ after reperfusion & Swerdlow & FNN & 63.0 & 17.3 & 64 & {$\left[\begin{array}{lll}3 & 3 & 1\end{array}\right]$} \\
\hline At $5 \mathrm{~h}$ after reperfusion & $\begin{array}{l}\text { Park- } \\
\text { Chiu }\end{array}$ & FNN & 54.7 & 14.7 & 64 & {$\left[\begin{array}{lll}3 & 4 & 3\end{array}\right]$} \\
\hline 5 hours of reperfusion & Binary & LSTM & 92.0 & 8.1 & 64 & {$\left[\begin{array}{llllll}2 & 3 & 3 & 4 & 1\end{array}\right]$} \\
\hline 5 hours of reperfusion & Swerdlow & LSTM & 93.0 & 7.6 & 64 & {$\left[\begin{array}{lllll}2 & 3 & 3 & 5 & 1\end{array}\right]$} \\
\hline 5 hours of reperfusion & $\begin{array}{l}\text { Park- } \\
\text { Chiu }\end{array}$ & LSTM & 87.5 & 9.6 & 64 & {$\left[\begin{array}{lllll}1 & 2 & 1 & 5 & 2\end{array}\right]$} \\
\hline
\end{tabular}

${ }^{1}$ Binary - irreversible or reversible damage, and the Swerdlow and Park-Chiu scales of tissue damage

Table 3 shows the confusion matrix for predictions of histological grading according to the Park-Chiu scale, based on 5 hours ( 6 repeated measurements) of bioimpedance data during reperfusion.

Table 3. Confusion matrix for classification on the Park-Chiu scale of ischemic injury based on the LSTM network and the 5 hours history ${ }^{1}$, presented as the mean over $10 \mathrm{RDCV}$ runs \pm one standard deviation over the runs, and the percentage of total predictions within the class. The false positive and false negative rates are provided for each class (same row, column 1).

\begin{tabular}{|c|c|c|c|c|c|c|c|}
\hline$n=64$ & $\begin{array}{l}\text { Predicted } \\
\text { class } 0\end{array}$ & $\begin{array}{l}\text { Predicted } \\
\text { class } 5\end{array}$ & $\begin{array}{l}\text { Predicted } \\
\text { class } 7\end{array}$ & $\begin{array}{l}\text { Predicted } \\
\text { class } 8\end{array}$ & Total & $\begin{array}{c}\text { False } \\
\text { positive } \\
\text { rate }\end{array}$ & $\begin{array}{l}\text { False } \\
\text { negative } \\
\text { rate }\end{array}$ \\
\hline $\begin{array}{l}\text { True } \\
\text { class } 0\end{array}$ & $\begin{array}{l}15.0 \pm 0.0 \\
(23.4 \%)\end{array}$ & $\begin{array}{c}0.0 \pm 0.0 \\
(0.0 \%)\end{array}$ & $\begin{array}{l}0.0 \pm 0.0 \\
(0.0 \%)\end{array}$ & $\begin{array}{c}0.0 \pm 0.0 \\
(0.0 \%)\end{array}$ & 15 & $0.8 \%$ & $0.0 \%$ \\
\hline $\begin{array}{l}\text { True } \\
\text { class } 5\end{array}$ & $\begin{array}{c}0.0 \pm 0.0 \\
(0.0 \%)\end{array}$ & $\begin{array}{l}14.8 \pm 0.6 \\
(23.1 \%)\end{array}$ & $\begin{array}{l}0.2 \pm 0.6 \\
(0.3 \%)\end{array}$ & $\begin{array}{c}0.0 \pm 0.0 \\
(0.0 \%)\end{array}$ & 15 & $0.2 \%$ & $1.3 \%$ \\
\hline $\begin{array}{l}\text { True } \\
\text { class } 7\end{array}$ & $\begin{array}{l}0.4 \pm 0.5 \\
(0.6 \%)\end{array}$ & $\begin{array}{c}0.1 \pm 0.3 \\
(0.2 \%)\end{array}$ & $\begin{array}{l}6.3 \pm 1.8 \\
(9.8 \%)\end{array}$ & $\begin{array}{l}4.2 \pm 1.8 \\
(6.6 \%)\end{array}$ & 11 & $6.2 \%$ & $42.7 \%$ \\
\hline $\begin{array}{l}\text { True } \\
\text { class } 8\end{array}$ & $\begin{array}{c}0.0 \pm 0.0 \\
(0.0 \%)\end{array}$ & $\begin{array}{c}0.0 \pm 0.0 \\
(0.0 \%)\end{array}$ & $\begin{array}{l}3.1 \pm 1.3 \\
(4.8 \%)\end{array}$ & $\begin{array}{l}19.9 \pm 1.3 \\
(31.1 \%)\end{array}$ & 23 & $10.2 \%$ & $13.5 \%$ \\
\hline Total & 15.4 & 14.9 & 9.6 & 24.1 & 64 & & \\
\hline
\end{tabular}

${ }^{1}$ Six repeated measurements

\section{Discussion}

The results indicate that good binary prediction of tissue viability (79.6\% mean accuracy) is possible based on one bioimpedance measurement after reperfusion and an FNN model, and that even better prediction is possible based on just one measurement performed before the initialization of reperfusion ( $91.5 \%$ mean, FNN model). When using the whole time-course of repeated bioimpedance measurement during the experiments a significantly higher accuracy (95.7\% mean) was obtained by utilizing a LSTM-RNN. With a clinical setting in mind we investigated the use of an LSTM-RNN model on shorter intervals of data history within the time-range that might be available intraoperatively. Using an LSTM-RNN model and two hours of reperfusion history gave a mean accuracy of $84.6 \%$ while five hours of reperfusion history gave a mean accuracy of $92.0 \%$. For classification based on the histological 
grading levels, the difference in performance was larger between the RNN and FNN networks. While 5 hours of reperfusion data enabled an $87.5 \%$ mean accuracy of prediction on the Park-Chiu scale using the LSTM-RNN, this accuracy was down to $54.7 \%$ when only using the measurement at $5 \mathrm{~h}$. These results indicate that the history of changes in bioimpedance during the reperfusion phase is important in the assessment of tissue viability.

\subsection{Advantages of time-series data and LSTM}

An obvious explanation for the improved accuracy with the LSTM-RNN model is the historical information included, from which the network can learn temporal patterns related to development of ischemic injury. Through the historical information, the LSTM-RNN network is provided with more relevant information related to the biological process during reperfusion (reflected in the bioimpedance measurement), when followed through a longer duration of measurement. For the FNN case, the accuracy is highest at the last measurement before reperfusion is initiated. This suggests that the most relevant information with respect to distinguishing between reversible and irreversible injury is at this time point, which is not accessible to the FNN when using a later time point after reperfusion is initiated ( $2 \mathrm{~h}$ or $5 \mathrm{~h}$ ), reducing the classification performance. As previously reported, after reperfusion, the time development of $\tan \delta \mathrm{m}$ amplitude and frequency overlap and periodically increase above the tan $\delta \mathrm{m}$ in the ischemic intestine. This shows that not only does reperfusion cause changes in the electrical parameters, but that these changes can be larger than the changes caused by ischemia itself. For an overview of the frequency dependency and time development of the bioimpedance data, see figures 1, 2, 4 in our previous paper (StrandAmundsen et al., 2018b).

Classification of ischemic small intestine injury is complex, as both the ischemic and reperfusion phases show similar characteristics and overlap in bioimpedance measurements at certain points during the ischemia/reperfusion course (Strand-Amundsen et al., 2018b). Classification using one measurement point (FNN model) relies only on discrimination using the feature space of the current input, with the model unable to know i.e. whether the $\tan \delta$ values are increasing or decreasing. A standard RNN is able to learn temporal patterns, but with increasing difficulty as the duration of the dependencies to be captured increases (Bengio et al., 1994). The LSTM units overcome this problem by the inherent memory function (input, output and forget gates), allowing recalling of values at arbitrary time intervals and classification of time-series of variable length and lags between important events (Hochreiter and Schmidhuber, 1997).

\subsection{Comparison with relevant work}

To our knowledge, the current study is the first to apply an LSTM network for classification based on bioimpedance measurements, and there are only a limited number of other studies on this method for classification of tissue status based on other biomedical sensors. Otte et al. applied bidirectional LSTM networks for classification of lung tumour tissue based on optical coherence tomography, outperforming other RNN architectures (Otte et al., 2013).

While it was reported fairly early that electrical impedance can be linked to intestinal viability (Carey et al., 1964), only some reports link "bioimpedance" and "accuracy" with respect to "viability" or "histological grading". Gonzalez et al. used intraluminal impedance spectroscopy on the mucosal tissue in the small bowel in pigs to provide an estimated ischemic injury classification and reported that this was a stable parameter for the health status of the tissue (Gonzalez et al., 2007). Beltran and Sacristan summarized the results from several studies (rabbit and pig), reporting that the impedance spectra changed with ischemia/reperfusion and that the changes in resistance and reactance associated with pathological changes observed by histology and also with the signal intensity of T2weighted images provided by magnetic resonance imaging (Beltran and Sacristan, 2015). Bloch et al. however evaluated this method and reported that they were not able to detect early changes in the electrical parameters of the alimentary tract during progressive hemorrhage or re-transfusion (Bloch et al., 2017). The results of Bloch et al. show that the previously reported results with intraluminal electrode catheters might be overrated. There is presently no bioimpedance method providing a solution for assessment of intestinal viability.

Other experimental approaches to intestinal viability have reported a close relationship between measurements on the small intestine and histological injury grade. Ando et al. reported that when using a non-contact laser tissue blood flowmeter on rabbit bowel, a significant relationship $(0.8, \mathrm{p}<0.0001)$ between the measurements and 
histological grade was found (Ando et al., 2000). They reported an accuracy of $76 \%$ and a sensitivity of $88 \%$ for assessment of bowel viability using a non-contact laser tissue blood flowmeter. Karakas et al. reported that when using diffuse reflectance spectroscopy on rat bowel, they found a strong consistency between histopathologic and spectroscopic results (Karakas et al., 2014).

Our results indicate that bioimpedance measurements together with an LSTM-RNN model can be used to predict the histological grade of ischemic/reperfused intestine with good accuracy (around 80\%), given that at least two hours of tissue data can be obtained during reperfusion.

\subsection{Validity of the pig model and data analysis for the clinical situation}

We selected the pig model as it has important anatomical and physiological similarities to humans (Douglas, 1972), the pathophysiology of ischemia/reperfusion in the pig model is similar to humans, and because the pig model has been suggested as a reference standard in intestinal transplantation research (Yandza et al., 2012). The segmental mesenteric occlusion model (Gonzalez et al., 2015) provides a well-defined area of ischemic injury affecting the whole intestinal wall in the occluded segment (Yandza et al., 2012). The segmental mesenteric occlusion model simulates ischemic injury as created during strangulation-ileus.

With respect to when bioimpedance data can be collected in a clinical setting, we estimate the time-window to be between the laparotomic identification of the putatively injured bowel segments, to the closing of the incision in the abdominal wall. As we found that using an LSTM-RNN with data history yielded higher accuracies than when using a FNN model with a single measurement, we wanted to investigate if it could be clinically feasible to perform measurements over a period of time during laparotomy. When we interviewed surgeons and anaesthesiologists at the Oslo University hospital, they reported that while there is a large variation, a rough estimate of a typical time window during laparotomy where the bowel is accessible can be from 2-5 hours. Thus, we investigated 2 and 5 hours durations, where the initial measurement was taken just before reperfusion and then for 2 or 5 hours of reperfusion. The results indicated that longer time-duration yielded higher accuracies (table 2 and figure 3 ). A possible approach to achieve a longer data history could be to leave a minimally invasive electrode setup on the surface of the putatively injured bowel segments for a period of time, following the initial laparotomy.

Our results indicate that bioimpedance measurements combined with neural network models have the potential to be a relevant tool for intraoperative assistance to the surgeon. A reduction of the need for second or third look operations will reduce the surgical stress for the patient, and a method with higher accuracy than the present standard has the potential to reduce the instances where wrong decisions are made.

The results suggest that not only is it possible to assess the viability of the intestinal tissue, but that it is also possible to use bioimpedance data to assess the level of histological injury according to well-known grading systems. For details about the histological grading systems and the viability assessment see paper (StrandAmundsen et al., 2018a).

\subsection{Limitations}

The classification model could probably have been tuned further by using a finer grid with more choices for each hyperparameter in the grid search, but a compromise had to be made between the grid size and the execution time of the RDCV loops. With complex classification algorithms such as deep learning with LSTM units, it is difficult to determine exactly which properties and temporal dependencies are captured from the training data, and whether there is information specific to the experiments in this study that is different or not available in other measuring situations. It is therefore important to test this method further on more relevant clinical settings before a conclusion on the clinical potential can be made.

In the process of placing bioimpedance electrodes against the jejunal wall, small variations in pressure was a potential source of variation in the bioimpedance measurements. While we tried to control the pressure, this effect cannot be excluded as a source of variation. Another potential source of variation in the bioimpedance measurements was the handling and exposure of the intestine to foreign materials during the course of the experiment, which can lead to tissue irritation (Torre et al., 2002). The contribution from contact impedance was low, due to the low 
intrinsic properties of the $\mathrm{Ag} / \mathrm{AgCl}$ electrodes, combined with the non-polarizable properties of $\mathrm{Ag} / \mathrm{AgCl}$. The electrode polarization impedance started to gradually dominate below $100 \mathrm{~Hz}$, and this did not change during the course of the experiment.

Evaluation of tissue viability based on histological assessment is difficult (Hillman, 2000), as the samples are small and lesions are heterogeneous in composition and distribution (Dabareiner et al., 2001) with areas of viable and necrotic tissue in the same tissue sample. Although we histologically observed injury to the jejunal wall that was considered irreversible, the ability to regenerate is likely to vary with the total volume of damaged tissue, making exact assessments from tissue samples difficult. Thus, we acknowledge that there is some uncertainty related to the accuracy of the histology-based viability reference that we used, and that follow up studies should be conducted to verify the accuracy of the reference.

Results from a previous experiment where we used a segmental mesenteric occlusion model, indicated that the sequence of ischemia/reperfusion injury in this model does not necessarily follow the outwards direction from the mucosa to the outer muscular layer, as most grading and classification systems suggest $[16,20]$. This affects the accuracy of the methods used with this model to grade histological injury (Park/Chiu, modified Swerdlow).

\section{Acknowledgements}

The main author is funded by the Norwegian Research council through the Integrisc project number 219819, and by Sensocure AS, Norway. The funding sources were not involved in the study design, collection, analysis and interpretation of data, in the writing of the report or in the decision to submit the article for publication. Both the dataset and the Matlab code used are available upon reasonable request by email to the corresponding author.

\section{Conclusion}

This analysis indicates that good prediction of small intestinal tissue viability is possible based on one bioimpedance measurement during reperfusion of ischemic small intestine, and that this measurement should be made just before the onset of reperfusion. Employing LSTM-RNN on repeated bioimpedance measurements during reperfusion allows good prediction of the level of injury. This prediction is even better, possibly close to $100 \%$ for detecting irreversible injury, when applying deep learning with LSTM-RNN on the whole time-course of bioimpedance changes during ischemia and reperfusion. LSTM-RNN's appears to be a promising tool for classification of multivariate time series of bioimpedance data.

\section{References}

Adavanne S, Parascandolo G, Pertila P, Heittola T and Virtanen T 2016 Sound Event Detection In Multichannel Audio Using Spatial And Harmonic Features. In: Detection and Classification of Acoustic Scenes and Events 2016, (Budapest, Hungary: Cornell University Library)

Ando M, Ito M, Nihei Z and Sugihara K 2000 Assessment of intestinal viability using a non-contact laser tissue blood flowmeter Am J Surg 180 176-80

Bala M, Kashuk J, Moore E E, Kluger Y, Biffl W, Gomes C A, Ben-Ishay O, Rubinstein C, Balogh Z J, Civil I, Coccolini F, Leppaniemi A, Peitzman A, Ansaloni L, Sugrue M, Sartelli M, Di Saverio S, Fraga G P and Catena F 2017 Acute mesenteric ischemia: guidelines of the World Society of Emergency Surgery World journal of emergency surgery : WJES 1238

Beltran N E and Sacristan E 2015 Gastrointestinal ischemia monitoring through impedance spectroscopy as a tool for the management of the critically ill Experimental biology and medicine $\mathbf{2 4 0} 835-45$

Bengio Y 2012 Practical Recommendations for Gradient-Based Training of Deep Architectures. (arXiv.org: Cornell University Library)

Bengio Y, Simard P and Frasconi P 1994 Learning Long-Term Dependencies with Gradient Descent Is Difficult Ieee T Neural Networ 5 157-66

Bloch A, Kohler A, Posthaus H, Berger D, Santos L, Jakob S, Takala J and Haenggi M 2017 Gastrointestinal Impedance Spectroscopy to Detect Hypoperfusion During Hemorrhage Shock 48 185-95

Brandt L J and Boley S J 2000 AGA technical review on intestinal ischemia. American Gastrointestinal Association Gastroenterology 118 954-68 
Bulkley G B, Zuidema G D, Hamilton S R, O'Mara C S, Klacsmann P G and Horn S D 1981 Intraoperative determination of small intestinal viability following ischemic injury: a prospective, controlled trial of two adjuvant methods (Doppler and fluorescein) compared with standard clinical judgment Annals of surgery 193 628-37

Carey L C, Kayser K, Ellison E H and Lepley D, Jr. 1964 Relative Electrical Impedance as Index to Intestinal Viability Archives of surgery $89226-8$

Chan K L, Chan K W and Tam P K H 1998 Segmental small bowel allograft-Ischemic injury and regeneration Journal of Pediatric Surgery 33 1703-6

Chiu C J, McArdle A H, Brown R, Scott H J and Gurd F N 1970 Intestinal mucosal lesion in low-flow states. I. A morphological, hemodynamic, and metabolic reappraisal Archives of surgery 101 478-83

Dabareiner R M, Sullins K E, White N A and Snyder J R 2001 Serosal injury in the equine jejunum and ascending colon after ischemia-reperfusion or intraluminal distention and decompression Veterinary surgery : VS 30 114-25

Douglas W R 1972 Of pigs and men and research: a review of applications and analogies of the pig, sus scrofa, in human medical research Space life sciences 3 226-34

Filzmoser P, Liebmann B and Varmuza K 2009 Repeated double cross validation J Chemometr 23 160-71

Gers F A and Schmidhuber E 2001 LSTM recurrent networks learn simple context-free and context-sensitive languages IEEE Trans Neural Netw 12 1333-40

Gonzalez C A, Villanueva C, Kaneko-Wada F T and Sacristan E 2007 Gastric tonometry and impedance spectroscopy as a guide to resuscitation therapy during experimental septic shock in pigs In Vivo 21 989-1001

Gonzalez C A, Villanueva C, Othman S, Narvaez R and Sacristan E 2003 Impedance spectroscopy for monitoring ischemic injury in the intestinal mucosa Physiological measurement 24 277-89

Gonzalez L M, Moeser A J and Blikslager A T 2015 Animal models of ischemia-reperfusion-induced intestinal injury: progress and promise for translational research American journal of physiology. Gastrointestinal and liver physiology 308 G6375

Hegde S S, Seidel S A, Ladipo J K, Bradshaw L A, Halter S and Richards W O 1998 Effects of mesenteric ischemia and reperfusion on small bowel electrical activity The Journal of surgical research 74 86-95

Herbert G S and Steele S R 2007 Acute and chronic mesenteric ischemia The Surgical clinics of North America 87 1115-34, ix Hillman H 2000 Limitations of clinical and biological histology Medical hypotheses 54 553-64

Hochreiter S and Schmidhuber J 1997 Long short-term memory Neural Comput 9 1735-80

Horgan P G and Gorey T F 1992 Operative assessment of intestinal viability The Surgical clinics of North America 72 143-55

Jurtz V I, Johansen A R, Nielsen M, Almagro Armenteros J J, Nielsen H, Sonderby C K, Winther O and Sonderby S K 2017 An introduction to deep learning on biological sequence data: examples and solutions Bioinformatics 33 3685-90

Karakas B R, Sircan-Kucuksayan A, Elpek O E and Canpolat M 2014 Investigating viability of intestine using spectroscopy: a pilot study The Journal of surgical research 191 91-8

Kudszus S, Roesel C, Schachtrupp A and Hoer J J 2010 Intraoperative laser fluorescence angiography in colorectal surgery: a noninvasive analysis to reduce the rate of anastomotic leakage Langenbecks Arch Surg 395 1025-30

Liu J, Shahroudy A, Xu D and Wang G 2016 Spatio-Temporal LSTM with Trust Gates for 3D Human Action Recognition. In: Computer Vision - ECCV 2016, (Amsterdam, The Netherlands: Springer) p 816

Matsuo H, Hirose H, Mori Y, Takagi H, Iwata H, Yamada T, Sakamoto K and Yasumura M 2004 Experimental studies to estimate the intestinal viability in a rat strangulated ileus model using a dielectric parameter Digestive diseases and sciences $49633-8$

Meng X, Liu L and Jiang H 2010 Indications and procedures for second-look surgery in acute mesenteric ischemia Surgery today $40700-5$

Noer R J and Derr J W 1949 Revascularization following experimental mesenteric vascular occlusion Archives of surgery $\mathbf{5 8}$ 576-89

Ordonez F J and Roggen D 2016 Deep Convolutional and LSTM Recurrent Neural Networks for Multimodal Wearable Activity Recognition Sensors (Basel) 16

Otte S, Otte C, Schlaefer A, Wittig L, Huttmann G, Dromann D and Zell A 2013 Oct a-Scan Based Lung Tumor Tissue Classification with Bidirectional Long Short Term Memory Networks Ieee Int Works Mach

Park P O, Haglund U, Bulkley G B and Falt K 1990 The sequence of development of intestinal tissue injury after strangulation ischemia and reperfusion Surgery 107 574-80

Plonka A J, Schentag J J, Messinger S, Adelman M H, Francis K L and Williams J S 1989 Effects of enteral and intravenous antimicrobial treatment on survival following intestinal ischemia in rats The Journal of surgical research 46 216-20

Redaelli C A, Schilling M K and Buchler M W 1998 Intraoperative laser Doppler flowmetry: a predictor of ischemic injury in acute mesenteric infarction Dig Surg 15 55-9

Seetharam P and Rodrigues G 2011 Short bowel syndrome: a review of management options Saudi J Gastroenterol 17 229-35

Strand-Amundsen R J, Reims H M, Reinholt F P, Ruud T E, Yang R, Hogetveit J O and Tonnessen T I 2018a Ischemia/reperfusion injury in porcine intestine - Viability assessment World journal of gastroenterology 24 2009-23 
Strand-Amundsen R J, Tronstad C, Kalvoy H, Gundersen Y, Krohn C D, Aasen A O, Holhjem L, Reims H M, Martinsen O G, Hogetveit J O, Ruud T E and Tonnessen T I 2016 In vivo characterization of ischemic small intestine using bioimpedance measurements Physiological measurement 37 257-75

Strand-Amundsen R J, Tronstad C, Kalvoy H, Ruud T E, Hogetveit J O, Martinsen O G and Tonnessen T I 2018b Small intestinal ischemia and reperfusion - bioimpedance measurements Physiological measurement

Surowiec A and Stuchly S S 1986 Use of the loss-tangent function in dielectric spectroscopy Bioelectromagnetics $7259-69$

Swerdlow S H, Antonioli D A and Goldman H 1981 Intestinal infarction: a new classification Archives of pathology \& laboratory medicine $\mathbf{1 0 5} 218$

Tilsed J V, Casamassima A, Kurihara H, Mariani D, Martinez I, Pereira J, Ponchietti L, Shamiyeh A, Al-Ayoubi F, Barco L A, Ceolin M, D'Almeida A J, Hilario S, Olavarria A L, Ozmen M M, Pinheiro L F, Poeze M, Triantos G, Fuentes F T, Sierra S U, Soreide K and Yanar H 2016 ESTES guidelines: acute mesenteric ischaemia European journal of trauma and emergency surgery : official publication of the European Trauma Society 42 253-70

Torre M, Favre A, Pini Prato A, Brizzolara A and Martucciello G 2002 Histologic study of peritoneal adhesions in children and in a rat model Pediatr Surg Int 18 673-6

Urbanavicius L, Pattyn P, de Putte D V and Venskutonis D 2011 How to assess intestinal viability during surgery: A review of techniques World journal of gastrointestinal surgery 3 59-69

Wang Y, Huang M, Zhao L and Zhu X 2016 Attention-based LSTM for Aspect-level Sentiment Classification. In: Proceedings of the 2016 Conference on Empirical Methods in Natural Language Processing, (Austin, Texas: Association for Computational Linguistics)

Wyers M C 2010 Acute mesenteric ischemia: diagnostic approach and surgical treatment Seminars in vascular surgery $\mathbf{2 3}$ 920

Yandza T, Tauc M, Saint-Paul M C, Ouaissi M, Gugenheim J and Hebuterne X 2012 The pig as a preclinical model for intestinal ischemia-reperfusion and transplantation studies The Journal of surgical research 178 807-19

Yousefi M R, Soheili M R, Breuel T M and Stricker D 2015 A comparison of 1D and 2D LSTM architectures for the recognition of handwritten Arabic. In: Document Recognition and Retrieval XXII, (San Francisco, California, USA 


\section{APPENDIX A: Confusion matrices for classification performance of the cases listed in Table 2.}

In this appendix, the confusion matrices, with false positive and false negative rates are shown for all cases represented in Table 2 in the main document.

Table 4. Confusion matrix for classification on the Park-Chiu scale of ischemic injury based on the LSTM network and the 5 hours history ${ }^{1}$, presented as the mean over $10 \mathrm{RDCV}$ runs \pm one standard deviation over the runs, and the percentage of total predictions within the class. The false positive and false negative rates are provided for each class (same row, column 1).

\begin{tabular}{|l|l|l|l|l|l|l|l|}
\hline $\mathrm{n}=64$ & $\begin{array}{l}\text { Predicted } \\
\text { class 0 }\end{array}$ & $\begin{array}{l}\text { Predicted } \\
\text { class 5 }\end{array}$ & $\begin{array}{l}\text { Predicted } \\
\text { class 7 }\end{array}$ & $\begin{array}{l}\text { Predicted } \\
\text { class 8 }\end{array}$ & Total & $\begin{array}{l}\text { False } \\
\text { positive } \\
\text { rate }\end{array}$ & $\begin{array}{l}\text { False } \\
\text { negative } \\
\text { rate }\end{array}$ \\
\hline $\begin{array}{l}\text { True } \\
\text { class 0 }\end{array}$ & $\begin{array}{l}15.0 \pm 0.0 \\
(23.4 \%)\end{array}$ & $\begin{array}{l}0.0 \pm 0.0 \\
(0.0 \%)\end{array}$ & $\begin{array}{l}0.0 \pm 0.0 \\
(0.0 \%)\end{array}$ & $\begin{array}{l}0.0 \pm 0.0 \\
(0.0 \%)\end{array}$ & 15 & $0.8 \%$ & $0.0 \%$ \\
\hline $\begin{array}{l}\text { True } \\
\text { class 5 }\end{array}$ & $\begin{array}{l}0.0 \pm 0.0 \\
(0.0 \%)\end{array}$ & $\begin{array}{l}14.8 \pm 0.6 \\
(23.1 \%)\end{array}$ & $\begin{array}{l}0.2 \pm 0.6 \\
(0.3 \%)\end{array}$ & $\begin{array}{l}0.0 \pm 0.0 \\
(0.0 \%)\end{array}$ & 15 & $0.2 \%$ & $1.3 \%$ \\
\hline $\begin{array}{l}\text { True } \\
\text { class 7 }\end{array}$ & $\begin{array}{l}0.4 \pm 0.5 \\
(0.6 \%)\end{array}$ & $\begin{array}{l}0.1 \pm 0.3 \\
(0.2 \%)\end{array}$ & $\begin{array}{l}6.3 \pm 1.8 \\
(9.8 \%)\end{array}$ & $\begin{array}{l}4.2 \pm 1.8 \\
(6.6 \%)\end{array}$ & 11 & $6.2 \%$ & $42.7 \%$ \\
\hline $\begin{array}{l}\text { True } \\
\text { class 8 }\end{array}$ & $\begin{array}{l}0.0 \pm 0.0 \\
(0.0 \%)\end{array}$ & $\begin{array}{l}0.0 \pm 0.0 \\
(0.0 \%)\end{array}$ & $\begin{array}{l}3.1 \pm 1.3 \\
(4.8 \%)\end{array}$ & $\begin{array}{l}19.9 \pm 1.3 \\
(31.1 \%)\end{array}$ & 23 & $10.2 \%$ & $13.5 \%$ \\
\hline Total & 15.4 & 14.9 & 9.6 & 24.1 & 64 & & \\
\hline
\end{tabular}

${ }^{1}$ Six repeated measurements

Table 5. Confusion matrix for classification on the Swerdlow scale of ischemic injury based on the LSTM network and the 5 hours history ${ }^{1}$, presented as the mean over $10 \mathrm{RDCV}$ runs \pm one standard deviation over the runs, and the percentage of total predictions within the class. The false positive and false negative rates are provided for each class (same row, column 1).

\begin{tabular}{|l|l|l|l|l|l|l|l|}
\hline $\mathrm{n}=64$ & $\begin{array}{l}\text { Predicted } \\
\text { class 0 }\end{array}$ & $\begin{array}{l}\text { Predicted } \\
\text { class 5 }\end{array}$ & $\begin{array}{l}\text { Predicted } \\
\text { class 7 }\end{array}$ & $\begin{array}{l}\text { Predicted } \\
\text { class 8 }\end{array}$ & Total & $\begin{array}{l}\text { False } \\
\text { positive } \\
\text { rate }\end{array}$ & $\begin{array}{l}\text { False } \\
\text { negative } \\
\text { rate }\end{array}$ \\
\hline $\begin{array}{l}\text { True } \\
\text { class 0 }\end{array}$ & $\begin{array}{l}15.0 \pm 0.0 \\
(23.4 \%)\end{array}$ & $\begin{array}{l}0.0 \pm 0.0 \\
(0.0 \%)\end{array}$ & $\begin{array}{l}0.0 \pm 0.0 \\
(0.0 \%)\end{array}$ & $\begin{array}{l}0.0 \pm 0.0 \\
(0.0 \%)\end{array}$ & 15 & $0.0 \%$ & $0.0 \%$ \\
\hline $\begin{array}{l}\text { True } \\
\text { class 5 }\end{array}$ & $\begin{array}{l}0.0 \pm 0.0 \\
(0.0 \%)\end{array}$ & $\begin{array}{l}15.0 \pm 0.0 \\
(23.4 \%)\end{array}$ & $\begin{array}{l}0.0 \pm 0.0 \\
(0.0 \%)\end{array}$ & $\begin{array}{l}0.0 \pm 0.0 \\
(0.0 \%)\end{array}$ & 15 & $0.4 \%$ & $0.0 \%$ \\
\hline $\begin{array}{l}\text { True } \\
\text { class 7 }\end{array}$ & $\begin{array}{l}0.0 \pm 0.0 \\
(0.0 \%)\end{array}$ & $\begin{array}{l}0.2 \pm 0.6 \\
(0.3 \%)\end{array}$ & $\begin{array}{l}8.1 \pm 0.9 \\
(12.7 \%)\end{array}$ & $\begin{array}{l}2.7 \pm 0.8 \\
(4.2 \%)\end{array}$ & 11 & $3.0 \%$ & $26.4 \%$ \\
\hline $\begin{array}{l}\text { True } \\
\text { class 8 }\end{array}$ & $\begin{array}{l}0.0 \pm 0.0 \\
(0.0 \%)\end{array}$ & $\begin{array}{l}0.0 \pm 0.0 \\
(0.0 \%)\end{array}$ & $\begin{array}{l}1.6 \pm 0.8 \\
(2.5 \%)\end{array}$ & $\begin{array}{l}21.4 \pm 0.8 \\
(33.4 \%)\end{array}$ & 23 & $6.6 \%$ & $7.0 \%$ \\
\hline Total & 15.0 & 15.2 & 9.7 & 24.1 & 64 & & \\
\hline
\end{tabular}

${ }^{1}$ Six repeated measurements 
Table 6. Confusion matrix for classification on the Swerdlow scale of ischemic injury based on the LSTM network and the 2 hours history ${ }^{1}$, presented as the mean over $10 \mathrm{RDCV}$ runs \pm one standard deviation over the runs, and the percentage of total predictions within the class. The false positive and false negative rates are provided for each class (same row, column 1).

\begin{tabular}{|l|l|l|l|l|l|l|l|}
\hline n=64 & $\begin{array}{l}\text { Predicted } \\
\text { class 0 }\end{array}$ & $\begin{array}{l}\text { Predicted } \\
\text { class 2 }\end{array}$ & $\begin{array}{l}\text { Predicted } \\
\text { class 5 }\end{array}$ & $\begin{array}{l}\text { Predicted } \\
\text { class 6 }\end{array}$ & Total & $\begin{array}{l}\text { False } \\
\text { positive } \\
\text { rate }\end{array}$ & $\begin{array}{l}\text { False } \\
\text { negative } \\
\text { rate }\end{array}$ \\
\hline $\begin{array}{l}\text { True } \\
\text { class 0 }\end{array}$ & $\begin{array}{l}15.0 \pm 0.0 \\
(23.4 \%)\end{array}$ & $\begin{array}{l}0.0 \pm 0.0 \\
(0.0 \%)\end{array}$ & $\begin{array}{l}0.0 \pm 0.0 \\
(0.0 \%)\end{array}$ & $\begin{array}{l}0.0 \pm 0.0 \\
(0.0 \%)\end{array}$ & 15 & $0.6 \%$ & $0.0 \%$ \\
\hline $\begin{array}{l}\text { True } \\
\text { class 2 }\end{array}$ & $\begin{array}{l}0.0 \pm 0.0 \\
(0.0 \%)\end{array}$ & $\begin{array}{l}14.0 \pm 0.7 \\
(21.9 \%)\end{array}$ & $\begin{array}{l}0.9 \pm 0.7 \\
(1.4 \%)\end{array}$ & $\begin{array}{l}0.1 \pm 0.3 \\
(0.2 \%)\end{array}$ & 15 & $6.5 \%$ & $6.7 \%$ \\
\hline $\begin{array}{l}\text { True } \\
\text { class 5 }\end{array}$ & $\begin{array}{l}0.0 \pm 0.0 \\
(0.0 \%)\end{array}$ & $\begin{array}{l}2.3 \pm 0.7 \\
(3.6 \%)\end{array}$ & $\begin{array}{l}2.0 \pm 0.8 \\
(3.1 \%)\end{array}$ & $\begin{array}{l}6.7 \pm 1.2 \\
(10.5 \%)\end{array}$ & 11 & $3.2 \%$ & $81.8 \%$ \\
\hline $\begin{array}{l}\text { True } \\
\text { class 6 }\end{array}$ & $\begin{array}{l}0.3 \pm 0.5 \\
(0.5 \%)\end{array}$ & $\begin{array}{l}0.9 \pm 0.3 \\
(1.4 \%)\end{array}$ & $\begin{array}{l}0.8 \pm 1.0 \\
(1.3 \%)\end{array}$ & $\begin{array}{l}21.0 \pm 0.8 \\
(32.8 \%)\end{array}$ & 23 & $16.6 \%$ & $8.7 \%$ \\
\hline Total & 15.3 & 17.2 & 3.7 & 27.8 & 64 & & \\
\hline
\end{tabular}

${ }^{1}$ Three repeated measurements

Table 7. Confusion matrix for classification on the Park-Chiu scale of ischemic injury based on the LSTM network and the 2 hours history ${ }^{1}$, presented as the mean over $10 \mathrm{RDCV}$ runs \pm one standard deviation over the runs, and the percentage of total predictions within the class. The false positive and false negative rates are provided for each class (same row, column 1).

\begin{tabular}{|l|l|l|l|l|l|l|l|}
\hline $\mathrm{n}=64$ & $\begin{array}{l}\text { Predicted } \\
\text { class 0 }\end{array}$ & $\begin{array}{l}\text { Predicted } \\
\text { class 5 }\end{array}$ & $\begin{array}{l}\text { Predicted } \\
\text { class 7 }\end{array}$ & $\begin{array}{l}\text { Predicted } \\
\text { class 8 }\end{array}$ & Total & $\begin{array}{l}\text { False } \\
\text { positive } \\
\text { rate }\end{array}$ & $\begin{array}{l}\text { False } \\
\text { negative } \\
\text { rate }\end{array}$ \\
\hline $\begin{array}{l}\text { True } \\
\text { class 0 }\end{array}$ & $\begin{array}{l}15.0 \pm 0.0 \\
(23.4 \%)\end{array}$ & $\begin{array}{l}0.0 \pm 0.0 \\
(0.0 \%)\end{array}$ & $\begin{array}{l}0.0 \pm 0.0 \\
(0.0 \%)\end{array}$ & $\begin{array}{l}0.0 \pm 0.0 \\
(0.0 \%)\end{array}$ & 15 & $1.0 \%$ & $0.0 \%$ \\
\hline $\begin{array}{l}\text { True } \\
\text { class 5 }\end{array}$ & $\begin{array}{l}0.0 \pm 0.0 \\
(0.0 \%)\end{array}$ & $\begin{array}{l}14.1 \pm 0.3 \\
(22.0 \%)\end{array}$ & $\begin{array}{l}0.9 \pm 0.3 \\
(1.4 \%)\end{array}$ & $\begin{array}{l}0.0 \pm 0.0 \\
(0.2 \%)\end{array}$ & 15 & $5.5 \%$ & $6.0 \%$ \\
\hline $\begin{array}{l}\text { True } \\
\text { class 7 }\end{array}$ & $\begin{array}{l}0.0 \pm 0.0 \\
(0.0 \%)\end{array}$ & $\begin{array}{l}2.2 \pm 0.6 \\
(3.4 \%)\end{array}$ & $\begin{array}{l}1.5 \pm 1.0 \\
(2.3 \%)\end{array}$ & $\begin{array}{l}7.3 \pm 0.9 \\
(11.4 \%)\end{array}$ & 11 & $3.4 \%$ & $86.4 \%$ \\
\hline $\begin{array}{l}\text { True } \\
\text { class 8 }\end{array}$ & $\begin{array}{l}0.5 \pm 0.8 \\
(0.8 \%)\end{array}$ & $\begin{array}{l}0.5 \pm 0.5 \\
(0.8 \%)\end{array}$ & $\begin{array}{l}0.9 \pm 1.0 \\
(1.4 \%)\end{array}$ & $\begin{array}{l}21.1 \pm 1.3 \\
(33.0 \%)\end{array}$ & 23 & $17.8 \%$ & $8.3 \%$ \\
\hline Total & 15.5 & 16.8 & 3.3 & 28.4 & 64 & & \\
\hline
\end{tabular}

${ }^{1}$ Three repeated measurements

Table 8. Confusion matrix for classification on the Park-Chiu scale of ischemic injury based on the LSTM network and the total recording history ${ }^{1}$, presented as the mean over $10 \mathrm{RDCV}$ runs \pm one standard deviation over the runs, and the percentage of total predictions within the class. The false positive and false negative rates are provided for each class (same row, column 1).

\begin{tabular}{|l|l|l|l|l|l|l|l|}
\hline $\mathrm{n}=79$ & $\begin{array}{l}\text { Predicted } \\
\text { class 0 }\end{array}$ & $\begin{array}{l}\text { Predicted } \\
\text { class 5 }\end{array}$ & $\begin{array}{l}\text { Predicted } \\
\text { class 7 }\end{array}$ & $\begin{array}{l}\text { Predicted } \\
\text { class 8 }\end{array}$ & Total & $\begin{array}{l}\text { False } \\
\text { positive } \\
\text { rate }\end{array}$ & $\begin{array}{l}\text { False } \\
\text { negative } \\
\text { rate }\end{array}$ \\
\hline
\end{tabular}




\begin{tabular}{|l|l|l|l|l|l|l|l|}
$\begin{array}{l}\text { True } \\
\text { class 0 }\end{array}$ & $\begin{array}{l}14.6 \pm 0.8 \\
(18.5 \%)\end{array}$ & $\begin{array}{l}0.4 \pm 0.8 \\
(0.5 \%)\end{array}$ & $\begin{array}{l}0.0 \pm 0.0 \\
(0.0 \%)\end{array}$ & $\begin{array}{l}0.0 \pm 0.0 \\
(0.0 \%)\end{array}$ & 15 & $3.1 \%$ & $2.7 \%$ \\
\hline $\begin{array}{l}\text { True } \\
\text { class 5 }\end{array}$ & $\begin{array}{l}2.0 \pm 1.3 \\
(2.5 \%)\end{array}$ & $\begin{array}{l}12.8 \pm 1.2 \\
(16.2 \%)\end{array}$ & $\begin{array}{l}0.1 \pm 0.3 \\
(0.1 \%)\end{array}$ & $\begin{array}{l}0.1 \pm 0.3 \\
(0.1 \%)\end{array}$ & 15 & $3.0 \%$ & $14.7 \%$ \\
\hline $\begin{array}{l}\text { True } \\
\text { class 7 }\end{array}$ & $\begin{array}{l}0.0 \pm 0.0 \\
(0.0 \%)\end{array}$ & $\begin{array}{l}1.3 \pm 0.5 \\
(1.6 \%)\end{array}$ & $\begin{array}{l}6.4 \pm 0.8 \\
(8.1 \%)\end{array}$ & $\begin{array}{l}3.3 \pm 1.1 \\
(4.2 \%)\end{array}$ & 11 & $2.1 \%$ & $41.8 \%$ \\
\hline $\begin{array}{l}\text { True } \\
\text { class 8 }\end{array}$ & $\begin{array}{l}0.0 \pm 0.8 \\
(0.0 \%)\end{array}$ & $\begin{array}{l}0.2 \pm 0.6 \\
(0.3 \%)\end{array}$ & $\begin{array}{l}1.3 \pm 0.9 \\
(1.6 \%)\end{array}$ & $\begin{array}{l}36.5 \pm 1.1 \\
(46.2 \%)\end{array}$ & 38 & $8.3 \%$ & $3.9 \%$ \\
\hline Total & 16.6 & 14.7 & 7.8 & 39.9 & 79 & & \\
\hline
\end{tabular}

${ }^{1}$ Ischemia and reperfusion

Table 9. Confusion matrix for classification on the Swerdlow scale of ischemic injury based on the LSTM network and the total recording history ${ }^{1}$, presented as the mean over $10 \mathrm{RDCV}$ runs \pm one standard deviation over the runs, and the percentage of total predictions within the class. The false positive and false negative rates are provided for each class (same row, column 1).

\begin{tabular}{|l|l|l|l|l|l|l|l|}
\hline $\mathrm{n}=79$ & $\begin{array}{l}\text { Predicted } \\
\text { class 0 }\end{array}$ & $\begin{array}{l}\text { Predicted } \\
\text { class 2 }\end{array}$ & $\begin{array}{l}\text { Predicted } \\
\text { class 5 }\end{array}$ & $\begin{array}{l}\text { Predicted } \\
\text { class 6 }\end{array}$ & Total & $\begin{array}{l}\text { False } \\
\text { positive } \\
\text { rate }\end{array}$ & $\begin{array}{l}\text { False } \\
\text { negative } \\
\text { rate }\end{array}$ \\
\hline $\begin{array}{l}\text { True } \\
\text { class 0 }\end{array}$ & $\begin{array}{l}14.5 \pm 0.8 \\
(18.4 \%)\end{array}$ & $\begin{array}{l}0.5 \pm 0.8 \\
(0.6 \%)\end{array}$ & $\begin{array}{l}0.0 \pm 0.0 \\
(0.0 \%)\end{array}$ & $\begin{array}{l}0.0 \pm 0.0 \\
(0.0 \%)\end{array}$ & 15 & $1.4 \%$ & $3.3 \%$ \\
\hline $\begin{array}{l}\text { True } \\
\text { class 2 }\end{array}$ & $\begin{array}{l}0.9 \pm 1.3 \\
(1.1 \%)\end{array}$ & $\begin{array}{l}13.9 \pm 1.3 \\
(17.6 \%)\end{array}$ & $\begin{array}{l}0.2 \pm 0.4 \\
(0.3 \%)\end{array}$ & $\begin{array}{l}0.0 \pm 0.0 \\
(0.0 \%)\end{array}$ & 15 & $2.8 \%$ & $7.3 \%$ \\
\hline $\begin{array}{l}\text { True } \\
\text { class 5 }\end{array}$ & $\begin{array}{l}0.0 \pm 0.0 \\
(0.0 \%)\end{array}$ & $1.2 \pm 0.6$ & $\begin{array}{l}6.9 \pm 1.1 \\
(1.5 \%)\end{array}$ & $\begin{array}{l}2.9 \pm 0.9 \\
(8.7 \%)\end{array}$ & 11 & $1.9 \%$ & $37.3 \%$ \\
\hline $\begin{array}{l}\text { True } \\
\text { class 6 }\end{array}$ & $\begin{array}{l}0.0 \pm 0.0 \\
(0.0 \%)\end{array}$ & $\begin{array}{l}0.1 \pm 0.3 \\
(0.1 \%)\end{array}$ & $\begin{array}{l}1.1 \pm 1.0 \\
(1.4 \%)\end{array}$ & $\begin{array}{l}36.8 \pm 1.2 \\
(46.6 \%)\end{array}$ & 38 & $7.1 \%$ & $3.2 \%$ \\
\hline Total & 15.4 & 15.7 & 8.2 & 39.7 & 79 & & \\
\hline
\end{tabular}

${ }^{1}$ Ischemia and reperfusion

Table 10. Confusion matrix for classification on the binary scale of ischemic injury based on the LSTM network and the total recording history ${ }^{1}$, presented as the mean over $10 \mathrm{RDCV}$ runs \pm one standard deviation over the runs, and the percentage of total predictions within the class. The false positive and false negative rates are provided for each class (same row, column 1).

\begin{tabular}{|l|l|l|l|l|l|}
\hline $\mathrm{n}=79$ & $\begin{array}{l}\text { Predicted } \\
\text { Reversible }\end{array}$ & $\begin{array}{l}\text { Predicted } \\
\text { Irreversible }\end{array}$ & Total & $\begin{array}{l}\text { False } \\
\text { positive } \\
\text { rate }\end{array}$ & $\begin{array}{l}\text { False } \\
\text { negative } \\
\text { rate }\end{array}$ \\
\hline $\begin{array}{l}\text { True } \\
\text { Reversible }\end{array}$ & $\begin{array}{l}39.6 \pm 0.8 \\
(50.1 \%)\end{array}$ & $\begin{array}{l}1.4 \pm 0.8 \\
(1.8 \%)\end{array}$ & 41 & $5.3 \%$ & $3.4 \%$ \\
\hline $\begin{array}{l}\text { True } \\
\text { Irreversible }\end{array}$ & $\begin{array}{l}2.0 \pm 1.2 \\
(2.5 \%)\end{array}$ & $\begin{array}{l}36.0 \pm 1.2 \\
(45.6 \%)\end{array}$ & 38 & $3.4 \%$ & $5.3 \%$ \\
\hline Total & 41.6 & 37.4 & 79 & & \\
\hline
\end{tabular}

${ }^{1}$ Ischemia and reperfusion 
Table 11. Confusion matrix for classification on the binary scale of ischemic injury based on the LSTM network and the 2 hours history ${ }^{1}$, presented as the mean over $10 \mathrm{RDCV}$ runs \pm one standard deviation over the runs, and the percentage of total predictions within the class. The false positive and false negative rates are provided for each class (same row, column 1).

\begin{tabular}{|l|l|l|l|l|l|}
\hline $\mathrm{n}=64$ & $\begin{array}{l}\text { Predicted } \\
\text { Reversible }\end{array}$ & $\begin{array}{l}\text { Predicted } \\
\text { Irreversible }\end{array}$ & Total & $\begin{array}{l}\text { False } \\
\text { positive } \\
\text { rate }\end{array}$ & $\begin{array}{l}\text { False } \\
\text { negative } \\
\text { rate }\end{array}$ \\
\hline $\begin{array}{l}\text { True } \\
\text { Reversible }\end{array}$ & $\begin{array}{l}36.1 \pm 0.7 \\
(56.4 \%)\end{array}$ & $\begin{array}{l}4.9 \pm 0.7 \\
(7.7 \%)\end{array}$ & 41 & $21.3 \%$ & $12.0 \%$ \\
\hline $\begin{array}{l}\text { True } \\
\text { Irreversible }\end{array}$ & $\begin{array}{l}4.9 \pm 1.4 \\
(7.7 \%)\end{array}$ & $\begin{array}{l}18.1 \pm 1.4 \\
(28.3 \%)\end{array}$ & 23 & $12.0 \%$ & $21.3 \%$ \\
\hline Total & 41.0 & 23.0 & 64 & & \\
\hline
\end{tabular}

${ }^{1}$ Three repeated measurements

Table 12. Confusion matrix for classification on the binary scale of ischemic injury based on the LSTM network and the 5 hours history ${ }^{1}$, presented as the mean over $10 \mathrm{RDCV}$ runs \pm one standard deviation over the runs, and the percentage of total predictions within the class. The false positive and false negative rates are provided for each class (same row, column 1).

\begin{tabular}{|l|l|l|l|l|l|}
\hline $\mathrm{n}=64$ & $\begin{array}{l}\text { Predicted } \\
\text { Reversible }\end{array}$ & $\begin{array}{l}\text { Predicted } \\
\text { Irreversible }\end{array}$ & Total & $\begin{array}{l}\text { False } \\
\text { positive } \\
\text { rate }\end{array}$ & $\begin{array}{l}\text { False } \\
\text { negative } \\
\text { rate }\end{array}$ \\
\hline $\begin{array}{l}\text { True } \\
\text { Reversible }\end{array}$ & $\begin{array}{l}38.2 \pm 0.9 \\
(59.7 \%)\end{array}$ & $\begin{array}{l}2.8 \pm 0.9 \\
(4.4 \%)\end{array}$ & 41 & $10.0 \%$ & $6.8 \%$ \\
\hline $\begin{array}{l}\text { True } \\
\text { Irreversible }\end{array}$ & $\begin{array}{l}2.3 \pm 0.8 \\
(3.6 \%)\end{array}$ & $\begin{array}{l}20.7 \pm 0.8 \\
(32.3 \%)\end{array}$ & 23 & $6.8 \%$ & $10.0 \%$ \\
\hline Total & 40.5 & 23.5 & 64 & & \\
\hline
\end{tabular}

${ }^{1}$ Six repeated measurements

Table 10. Confusion matrix for classification on the Park-Chiu scale of ischemic injury based on the FNN network and the measurement at the last time point before reperfusion was initiated, presented as the mean over $10 \mathrm{RDCV}$ runs \pm one standard deviation over the runs, and the percentage of total predictions within the class. The false positive and false negative rates are provided for each class (same row, column 1).

\begin{tabular}{|l|l|l|l|l|l|l|l|}
\hline $\mathrm{n}=64$ & $\begin{array}{l}\text { Predicted } \\
\text { class 0 }\end{array}$ & $\begin{array}{l}\text { Predicted } \\
\text { class 5 }\end{array}$ & $\begin{array}{l}\text { Predicted } \\
\text { class 7 }\end{array}$ & $\begin{array}{l}\text { Predicted } \\
\text { class 8 }\end{array}$ & Total & $\begin{array}{l}\text { False } \\
\text { positive } \\
\text { rate }\end{array}$ & $\begin{array}{l}\text { False } \\
\text { negative } \\
\text { rate }\end{array}$ \\
\hline $\begin{array}{l}\text { True } \\
\text { class 0 }\end{array}$ & $\begin{array}{l}11.9 \pm 2.7 \\
(18.4 \%)\end{array}$ & $\begin{array}{l}1.4 \pm 1.6 \\
(0.6 \%)\end{array}$ & $\begin{array}{l}1.0 \pm 1.5 \\
(0.0 \%)\end{array}$ & $\begin{array}{l}0.7 \pm 0.7 \\
(0.0 \%)\end{array}$ & 15 & $10.4 \%$ & $20.7 \%$ \\
\hline $\begin{array}{l}\text { True } \\
\text { class 5 }\end{array}$ & $\begin{array}{l}3.9 \pm 1.1 \\
(1.1 \%)\end{array}$ & $\begin{array}{l}9.2 \pm 2.4 \\
(17.6 \%)\end{array}$ & $\begin{array}{l}1.4 \pm 1.6 \\
(0.3 \%)\end{array}$ & $\begin{array}{l}0.5 \pm 1.6 \\
(0.0 \%)\end{array}$ & 15 & $7.3 \%$ & $38.7 \%$ \\
\hline $\begin{array}{l}\text { True } \\
\text { class 7 }\end{array}$ & $1.2 \pm 1.0$ & $2.2 \pm 1.9$ & $3.2 \pm 1.6$ & $4.4 \pm 1.6$ & 11 & $8.3 \%$ & $70.9 \%$ \\
\hline
\end{tabular}




\begin{tabular}{|l|l|l|l|l|l|l|l|}
$\begin{array}{l}\text { True } \\
\text { class 8 }\end{array}$ & $\begin{array}{l}0.0 \pm 0.0 \\
(0.0 \%)\end{array}$ & $\begin{array}{l}0.0 \pm 0.0 \\
(0.1 \%)\end{array}$ & $\begin{array}{l}2.0 \pm 1.8 \\
(1.4 \%)\end{array}$ & $\begin{array}{l}21.0 \pm 1.8 \\
(46.6 \%)\end{array}$ & 23 & $13.7 \%$ & $8.7 \%$ \\
\hline Total & 17.0 & 12.8 & 7.6 & 26.6 & 64 & & \\
\hline
\end{tabular}

Table 11. Confusion matrix for classification on the binary scale of ischemic injury based on the FNN network and the measurement at the last time point before reperfusion was initiated, presented as the mean over $10 \mathrm{RDCV}$ runs \pm one standard deviation over the runs, and the percentage of total predictions within the class. The false positive and false negative rates are provided for each class (same row, column 1).

\begin{tabular}{|l|l|l|l|l|l|}
\hline $\mathrm{n}=79$ & $\begin{array}{l}\text { Predicted } \\
\text { Reversible }\end{array}$ & $\begin{array}{l}\text { Predicted } \\
\text { Irreversible }\end{array}$ & Total & $\begin{array}{l}\text { False } \\
\text { positive } \\
\text { rate }\end{array}$ & $\begin{array}{l}\text { False } \\
\text { negative } \\
\text { rate }\end{array}$ \\
\hline $\begin{array}{l}\text { True } \\
\text { Reversible }\end{array}$ & $\begin{array}{l}38.1 \pm 3.3 \\
(59.5 \%)\end{array}$ & $\begin{array}{l}2.9 \pm 3.3 \\
(4.5 \%)\end{array}$ & 41 & $10.3 \%$ & $7.1 \%$ \\
\hline $\begin{array}{l}\text { True } \\
\text { Irreversible }\end{array}$ & $\begin{array}{l}3.9 \pm 3.3 \\
(6.1 \%)\end{array}$ & $\begin{array}{l}34.1 \pm 3.3 \\
(53.3 \%)\end{array}$ & 38 & $7.1 \%$ & $10.3 \%$ \\
\hline Total & 42.0 & 37.0 & 79 & & \\
\hline
\end{tabular}

Table 12. Confusion matrix for classification on the binary scale of ischemic injury based on the FNN network and the last measurement of the experiment ${ }^{1}$, presented as the mean over $10 \mathrm{RDCV}$ runs \pm one standard deviation over the runs, and the percentage of total predictions within the class. The false positive and false negative rates are provided for each class (same row, column 1).

\begin{tabular}{|l|l|l|l|l|l|}
\hline $\mathrm{n}=79$ & $\begin{array}{l}\text { Predicted } \\
\text { Reversible }\end{array}$ & $\begin{array}{l}\text { Predicted } \\
\text { Irreversible }\end{array}$ & Total & $\begin{array}{l}\text { False } \\
\text { positive } \\
\text { rate }\end{array}$ & $\begin{array}{l}\text { False } \\
\text { negative } \\
\text { rate }\end{array}$ \\
\hline $\begin{array}{l}\text { True } \\
\text { Reversible }\end{array}$ & $\begin{array}{l}33.7 \pm 1.6 \\
(59.5 \%)\end{array}$ & $\begin{array}{l}7.3 \pm 1.6 \\
(4.5 \%)\end{array}$ & 41 & $23.2 \%$ & $17.8 \%$ \\
\hline $\begin{array}{l}\text { True } \\
\text { Irreversible }\end{array}$ & $\begin{array}{l}8.8 \pm 5.6 \\
(6.1 \%)\end{array}$ & $\begin{array}{l}29.2 \pm 5.6 \\
(53.3 \%)\end{array}$ & 38 & $17.8 \%$ & $23.2 \%$ \\
\hline Total & 42.0 & 37.0 & 79 & & \\
\hline
\end{tabular}

${ }^{1}$ After reperfusion

Table 13. Confusion matrix for classification on the Swerdlow scale of ischemic injury based on the FNN network and the last measurement of the experiment ${ }^{1}$, presented as the mean over $10 \mathrm{RDCV}$ runs \pm one standard deviation over the runs, and the percentage of total predictions within the class. The false positive and false negative rates are provided for each class (same row, column 1).

\begin{tabular}{|l|l|l|l|l|l|l|l|}
\hline $\mathrm{n}=79$ & $\begin{array}{l}\text { Predicted } \\
\text { class 0 }\end{array}$ & $\begin{array}{l}\text { Predicted } \\
\text { class 2 }\end{array}$ & $\begin{array}{l}\text { Predicted } \\
\text { class 5 }\end{array}$ & $\begin{array}{l}\text { Predicted } \\
\text { class 6 }\end{array}$ & Total & $\begin{array}{l}\text { False } \\
\text { positive } \\
\text { rate }\end{array}$ & $\begin{array}{l}\text { False } \\
\text { negative } \\
\text { rate }\end{array}$ \\
\hline $\begin{array}{l}\text { True } \\
\text { class 0 }\end{array}$ & $\begin{array}{l}8.9 \pm 4.2 \\
(11.3 \%)\end{array}$ & $\begin{array}{l}5.0 \pm 4.2 \\
(6.3 \%)\end{array}$ & $\begin{array}{l}0.3 \pm 0.7 \\
(0.4 \%)\end{array}$ & $\begin{array}{l}0.8 \pm 1.1 \\
(1.0 \%)\end{array}$ & 15 & $5.8 \%$ & $40.7 \%$ \\
\hline $\begin{array}{l}\text { True } \\
\text { class 2 }\end{array}$ & $\begin{array}{l}2.6 \pm 2.4 \\
(3.3 \%)\end{array}$ & $\begin{array}{l}10.1 \pm 4.1 \\
(12.8 \%)\end{array}$ & $\begin{array}{l}1.1 \pm 1.9 \\
(1.4 \%)\end{array}$ & $\begin{array}{l}1.2 \pm 1.9 \\
(1.5 \%)\end{array}$ & 15 & $13.1 \%$ & $32.7 \%$ \\
\hline $\begin{array}{l}\text { True } \\
\text { class 5 }\end{array}$ & $\begin{array}{l}0.4 \pm 0.7 \\
(0.5 \%)\end{array}$ & $\begin{array}{l}1.5 \pm 1.4 \\
(1.9 \%)\end{array}$ & $\begin{array}{l}0.5 \pm 1.0 \\
(0.6 \%)\end{array}$ & $\begin{array}{l}8.6 \pm 1.3 \\
(10.9 \%)\end{array}$ & 11 & $5.6 \%$ & $95.4 \%$ \\
\hline
\end{tabular}




\begin{tabular}{|l|l|l|l|l|l|l|l|}
$\begin{array}{l}\text { True } \\
\text { class 6 }\end{array}$ & $\begin{array}{l}0.7 \pm 1.1 \\
(0.9 \%)\end{array}$ & $\begin{array}{l}1.9 \pm 1.8 \\
(2.4 \%)\end{array}$ & $\begin{array}{l}2.4 \pm 3.1 \\
(3.0 \%)\end{array}$ & $\begin{array}{l}33.0 \pm 3.7 \\
(41.8 \%)\end{array}$ & 38 & $25.9 \%$ & $13.2 \%$ \\
\hline Total & 12.6 & 18.5 & 4.3 & 43.6 & 79 & & \\
\hline
\end{tabular}

${ }^{1}$ After reperfusion

Table 14. Confusion matrix for classification on the Park-Chiu scale of ischemic injury based on the FNN network and the last measurement of the experiment ${ }^{1}$, presented as the mean over $10 \mathrm{RDCV}$ runs \pm one standard deviation over the runs, and the percentage of total predictions within the class. The false positive and false negative rates are provided for each class (same row, column 1).

\begin{tabular}{|l|l|l|l|l|l|l|l|}
\hline n=79 & $\begin{array}{l}\text { Predicted } \\
\text { class 0 }\end{array}$ & $\begin{array}{l}\text { Predicted } \\
\text { class 5 }\end{array}$ & $\begin{array}{l}\text { Predicted } \\
\text { class 7 }\end{array}$ & $\begin{array}{l}\text { Predicted } \\
\text { class 8 }\end{array}$ & Total & $\begin{array}{l}\text { False } \\
\text { positive } \\
\text { rate }\end{array}$ & $\begin{array}{l}\text { False } \\
\text { negative } \\
\text { rate }\end{array}$ \\
\hline $\begin{array}{l}\text { True } \\
\text { class 0 }\end{array}$ & $\begin{array}{l}11.4 \pm 2.7 \\
(14.4 \%)\end{array}$ & $\begin{array}{l}3.4 \pm 2.8 \\
(4.3 \%)\end{array}$ & $\begin{array}{l}0.0 \pm 1.0 \\
(0.0 \%)\end{array}$ & $\begin{array}{l}0.2 \pm 0.6 \\
(0.3 \%)\end{array}$ & 15 & $12.3 \%$ & $24.0 \%$ \\
\hline $\begin{array}{l}\text { True } \\
\text { class 5 }\end{array}$ & $\begin{array}{l}5.8 \pm 2.1 \\
(7.3 \%)\end{array}$ & $\begin{array}{l}8.3 \pm 2.2 \\
(10.5 \%)\end{array}$ & $\begin{array}{l}0.1 \pm 0.3 \\
(0.1 \%)\end{array}$ & $\begin{array}{l}0.8 \pm 1.8 \\
(1.0 \%)\end{array}$ & 15 & $8.6 \%$ & $44.7 \%$ \\
\hline $\begin{array}{l}\text { True } \\
\text { class 7 }\end{array}$ & $\begin{array}{l}1.0 \pm 0.8 \\
(1.3 \%)\end{array}$ & $\begin{array}{l}0.7 \pm 0.7 \\
(0.9 \%)\end{array}$ & $\begin{array}{l}0.3 \pm 0.5 \\
(0.4 \%)\end{array}$ & $\begin{array}{l}9.0 \pm 0.8 \\
(11.4 \%)\end{array}$ & 11 & $2.4 \%$ & $97.3 \%$ \\
\hline $\begin{array}{l}\text { True } \\
\text { class 8 }\end{array}$ & $\begin{array}{l}1.1 \pm 2.1 \\
(1.4 \%)\end{array}$ & $1.4 \pm 1.3$ & $1.5 \pm 1.2$ & $34.0 \pm 1.6$ & 38 & $24.4 \%$ & $10.5 \%$ \\
\hline$(1.8 \%)$ & $(1.9 \%)$ & $(43.0 \%)$ & 38 & & \\
\hline Total & 19.3 & 13.8 & 1.9 & 44.0 & 79 & & \\
\hline
\end{tabular}

${ }^{1}$ After reperfusion

Table 15. Confusion matrix for classification on the binary scale of ischemic injury based on the FNN network and the measurement at two hours after reperfusion was initiated, presented as the mean over $10 \mathrm{RDCV}$ runs \pm one standard deviation over the runs, and the percentage of total predictions within the class. The false positive and false negative rates are provided for each class (same row, column 1).

\begin{tabular}{|l|l|l|l|l|l|}
\hline $\mathrm{n}=64$ & $\begin{array}{l}\text { Predicted } \\
\text { Reversible }\end{array}$ & $\begin{array}{l}\text { Predicted } \\
\text { Irreversible }\end{array}$ & Total & $\begin{array}{l}\text { False } \\
\text { positive } \\
\text { rate }\end{array}$ & $\begin{array}{l}\text { False } \\
\text { negative } \\
\text { rate }\end{array}$ \\
\hline $\begin{array}{l}\text { True } \\
\text { Reversible }\end{array}$ & $\begin{array}{l}34.9 \pm 2.3 \\
(54.5 \%)\end{array}$ & $\begin{array}{l}6.1 \pm 2.3 \\
(9.5 \%)\end{array}$ & 41 & $33.5 \%$ & $14.9 \%$ \\
\hline $\begin{array}{l}\text { True } \\
\text { Irreversible }\end{array}$ & $\begin{array}{l}7.7 \pm 0.9 \\
(12.0 \%)\end{array}$ & $\begin{array}{l}15.3 \pm 0.9 \\
(23.9 \%)\end{array}$ & 23 & $14.9 \%$ & $33.5 \%$ \\
\hline Total & 42.6 & 21.4 & 64 & & \\
\hline
\end{tabular}

Table 16. Confusion matrix for classification on the binary scale of ischemic injury based on the FNN network and the measurement at five hours after reperfusion was initiated, presented as the mean over $10 \mathrm{RDCV}$ runs \pm one standard deviation over the runs, and the percentage of total predictions within the class. The false positive and false negative rates are provided for each class (same row, column 1).

\begin{tabular}{|l|l|l|l|l|l|}
\hline $\mathrm{n}=64$ & $\begin{array}{l}\text { Predicted } \\
\text { Reversible }\end{array}$ & $\begin{array}{l}\text { Predicted } \\
\text { Irreversible }\end{array}$ & Total & $\begin{array}{l}\text { False } \\
\text { positive } \\
\text { rate }\end{array}$ & $\begin{array}{l}\text { False } \\
\text { negative } \\
\text { rate }\end{array}$ \\
\hline
\end{tabular}




\begin{tabular}{|l|l|l|l|l|l|}
$\begin{array}{l}\text { True } \\
\text { Reversible }\end{array}$ & $\begin{array}{l}35.2 \pm 1.2 \\
(55.0 \%)\end{array}$ & $\begin{array}{l}5.8 \pm 1.2 \\
(9.1 \%)\end{array}$ & 41 & $25.2 \%$ & $14.1 \%$ \\
\hline $\begin{array}{l}\text { True } \\
\text { Irreversible }\end{array}$ & $\begin{array}{l}5.8 \pm 2.1 \\
(9.1 \%)\end{array}$ & $\begin{array}{l}17.2 \pm 2.1 \\
(26.9 \%)\end{array}$ & 23 & $14.1 \%$ & $25.2 \%$ \\
\hline Total & 41.0 & 23.0 & 64 & & \\
\hline
\end{tabular}

Table 17. Confusion matrix for classification on the Park-Chiu scale of ischemic injury based on the FNN network and the measurement at two hours after reperfusion was initiated, presented as the mean over $10 \mathrm{RDCV}$ runs \pm one standard deviation over the runs, and the percentage of total predictions within the class. The false positive and false negative rates are provided for each class (same row, column 1).

\begin{tabular}{|l|l|l|l|l|l|l|l|}
\hline $\mathrm{n}=64$ & $\begin{array}{l}\text { Predicted } \\
\text { class 0 }\end{array}$ & $\begin{array}{l}\text { Predicted } \\
\text { class 5 }\end{array}$ & $\begin{array}{l}\text { Predicted } \\
\text { class 7 }\end{array}$ & $\begin{array}{l}\text { Predicted } \\
\text { class 8 }\end{array}$ & Total & $\begin{array}{l}\text { False } \\
\text { positive } \\
\text { rate }\end{array}$ & $\begin{array}{l}\text { False } \\
\text { negative } \\
\text { rate }\end{array}$ \\
\hline $\begin{array}{l}\text { True } \\
\text { class 0 }\end{array}$ & $\begin{array}{l}14.8 \pm 0.6 \\
(23.1 \%)\end{array}$ & $\begin{array}{l}0.2 \pm 0.6 \\
(0.3 \%)\end{array}$ & $\begin{array}{l}0.0 \pm 100 \\
(0.0 \%)\end{array}$ & $\begin{array}{l}0.0 \pm 0.0 \\
(0.0 \%)\end{array}$ & 15 & $30.0 \%$ & $1.3 \%$ \\
\hline $\begin{array}{l}\text { True } \\
\text { class 5 }\end{array}$ & $\begin{array}{l}4.4 \pm 1.9 \\
(6.9 \%)\end{array}$ & $\begin{array}{l}10.5 \pm 2.0 \\
(16.4 \%)\end{array}$ & $\begin{array}{l}0.0 \pm 0.0 \\
(0.0 \%)\end{array}$ & $\begin{array}{l}0.1 \pm 0.3 \\
(0.2 \%)\end{array}$ & 15 & $1.8 \%$ & $30.0 \%$ \\
\hline $\begin{array}{l}\text { True } \\
\text { class 7 }\end{array}$ & $\begin{array}{l}4.0 \pm 1.1 \\
(6.3 \%)\end{array}$ & $\begin{array}{l}0.3 \pm 0.7 \\
(0.5 \%)\end{array}$ & $\begin{array}{l}0.0 \pm 0.0 \\
(0.0 \%)\end{array}$ & $\begin{array}{l}6.7 \pm 1.5 \\
(10.5 \%)\end{array}$ & 11 & $0.6 \%$ & $100.0 \%$ \\
\hline $\begin{array}{l}\text { True } \\
\text { class 8 }\end{array}$ & $\begin{array}{l}6.3 \pm 2.2 \\
(9.8 \%)\end{array}$ & $0.4 \pm 0.7$ & $0.3 \pm 0.5$ & $16.0 \pm 2.4$ & 23 & $16.6 \%$ & $30.4 \%$ \\
$(0.6 \%)$ & $(0.5 \%)$ & $(25.0 \%)$ & 23 & & \\
\hline Total & 29.5 & 11.4 & 0.3 & 22.8 & 64 & & \\
\hline
\end{tabular}

Table 18. Confusion matrix for classification on the Park-Chiu scale of ischemic injury based on the FNN network and the measurement at five hours after reperfusion was initiated, presented as the mean over $10 \mathrm{RDCV}$ runs \pm one standard deviation over the runs, and the percentage of total predictions within the class. The false positive and false negative rates are provided for each class (same row, column 1).

\begin{tabular}{|l|l|l|l|l|l|l|l|}
\hline $\mathrm{n}=64$ & $\begin{array}{l}\text { Predicted } \\
\text { class 0 }\end{array}$ & $\begin{array}{l}\text { Predicted } \\
\text { class 5 }\end{array}$ & $\begin{array}{l}\text { Predicted } \\
\text { class 7 }\end{array}$ & $\begin{array}{l}\text { Predicted } \\
\text { class 8 }\end{array}$ & Total & $\begin{array}{l}\text { False } \\
\text { positive } \\
\text { rate }\end{array}$ & $\begin{array}{l}\text { False } \\
\text { negative } \\
\text { rate }\end{array}$ \\
\hline $\begin{array}{l}\text { True } \\
\text { class 0 }\end{array}$ & $\begin{array}{l}13.5 \pm 0.6 \\
(21.1 \%)\end{array}$ & $\begin{array}{l}1.1 \pm 0.6 \\
(1.7 \%)\end{array}$ & $\begin{array}{l}0.4 \pm 100 \\
(0.6 \%)\end{array}$ & $\begin{array}{l}0.0 \pm 0.0 \\
(0.0 \%)\end{array}$ & 15 & $33.9 \%$ & $10.0 \%$ \\
\hline $\begin{array}{l}\text { True } \\
\text { class 5 }\end{array}$ & $\begin{array}{l}10.6 \pm 1.9 \\
(16.6 \%)\end{array}$ & $\begin{array}{l}3.5 \pm 2.0 \\
(5.5 \%)\end{array}$ & $\begin{array}{l}0.8 \pm 0.0 \\
(1.3 \%)\end{array}$ & $\begin{array}{l}0.1 \pm 0.3 \\
(0.2 \%)\end{array}$ & 15 & $6.3 \%$ & $76.7 \%$ \\
\hline $\begin{array}{l}\text { True } \\
\text { class 7 }\end{array}$ & $\begin{array}{l}3.1 \pm 1.1 \\
(4.8 \%)\end{array}$ & $1.4 \pm 0.7$ & $\begin{array}{l}0.5 \pm 0.0 \\
(2.2 \%)\end{array}$ & $\begin{array}{l}6.0 \pm 1.5 \\
(0.8 \%)\end{array}$ & 11 & $6.0 \%$ & $95.5 \%$ \\
\hline $\begin{array}{l}\text { True } \\
\text { class 8 }\end{array}$ & $\begin{array}{l}2.9 \pm 2.2 \\
(4.5 \%)\end{array}$ & $0.6 \pm 0.7$ & $2.0 \pm 0.5$ & $17.5 \pm 2.4$ & 23 & $14.9 \%$ & $23.9 \%$ \\
\hline Total & $30.9 \%)$ & $(3.1 \%)$ & $(27.3 \%)$ & 23 & & \\
\hline
\end{tabular}


Table 19. Confusion matrix for classification on the Swerdlow scale of ischemic injury based on the FNN network and the first measurement before reperfusion was initiated, presented as the mean over $10 \mathrm{RDCV}$ runs \pm one standard deviation over the runs, and the percentage of total predictions within the class. The false positive and false negative rates are provided for each class (same row, column 1).

\begin{tabular}{|c|c|c|c|c|c|c|c|}
\hline $\mathrm{n}=79$ & $\begin{array}{l}\text { Predicted } \\
\text { class 0 }\end{array}$ & $\begin{array}{l}\text { Predicted } \\
\text { class } 2\end{array}$ & $\begin{array}{l}\text { Predicted } \\
\text { class } 5\end{array}$ & $\begin{array}{l}\text { Predicted } \\
\text { class } 6\end{array}$ & Total & $\begin{array}{l}\text { False } \\
\text { positive } \\
\text { rate }\end{array}$ & $\begin{array}{l}\text { False } \\
\text { negative } \\
\text { rate }\end{array}$ \\
\hline $\begin{array}{l}\text { True } \\
\text { class } 0\end{array}$ & $\begin{array}{l}14.0 \pm 1.6 \\
(17.7 \%)\end{array}$ & $\begin{array}{l}0.4 \pm 0.7 \\
(0.5 \%)\end{array}$ & $\begin{array}{l}0.5 \pm 1.3 \\
(0.6 \%)\end{array}$ & $\begin{array}{l}0.1 \pm 0.3 \\
(0.1 \%)\end{array}$ & 15 & $16.9 \%$ & $6.7 \%$ \\
\hline $\begin{array}{l}\text { True } \\
\text { class } 2\end{array}$ & $\begin{array}{l}5.7 \pm 2.4 \\
(7.2 \%)\end{array}$ & $\begin{array}{l}6.7 \pm 2.9 \\
(8.5 \%)\end{array}$ & $\begin{array}{l}1.6 \pm 1.2 \\
(2.0 \%)\end{array}$ & $\begin{array}{l}1.0 \pm 1.8 \\
(1.3 \%)\end{array}$ & 15 & $2.7 \%$ & $55.3 \%$ \\
\hline $\begin{array}{l}\text { True } \\
\text { class } 5\end{array}$ & $\begin{array}{l}2.4 \pm 2.2 \\
(3.0 \%)\end{array}$ & $\begin{array}{l}1.1 \pm 0.9 \\
(1.4 \%)\end{array}$ & $\begin{array}{l}4.0 \pm 1.6 \\
(5.1 \%)\end{array}$ & $\begin{array}{l}3.5 \pm 1.6 \\
(4.4 \%)\end{array}$ & 11 & $6.8 \%$ & $63.6 \%$ \\
\hline $\begin{array}{l}\text { True } \\
\text { class } 6\end{array}$ & $\begin{array}{l}2.7 \pm 1.8 \\
(3.4 \%)\end{array}$ & $\begin{array}{l}0.2 \pm 0.4 \\
(0.3 \%)\end{array}$ & $\begin{array}{l}2.5 \pm 1.1 \\
(3.2 \%)\end{array}$ & $\begin{array}{l}32.6 \pm 2.3 \\
(41.3 \%)\end{array}$ & 38 & $11.2 \%$ & $14.2 \%$ \\
\hline Total & 24.8 & 8.4 & 8.6 & 37.2 & 79 & & \\
\hline
\end{tabular}

Table 20. Confusion matrix for classification on the Swerdlow scale of ischemic injury based on the FNN network and the measurement point at two hours of reperfusion, presented as the mean over $10 \mathrm{RDCV}$ runs \pm one standard deviation over the runs, and the percentage of total predictions within the class. The false positive and false negative rates are provided for each class (same row, column 1).

\begin{tabular}{|l|l|l|l|l|l|l|l|}
\hline $\mathrm{n}=64$ & $\begin{array}{l}\text { Predicted } \\
\text { class 0 }\end{array}$ & $\begin{array}{l}\text { Predicted } \\
\text { class 2 }\end{array}$ & $\begin{array}{l}\text { Predicted } \\
\text { class 5 }\end{array}$ & $\begin{array}{l}\text { Predicted } \\
\text { class 6 }\end{array}$ & Total & $\begin{array}{l}\text { False } \\
\text { positive } \\
\text { rate }\end{array}$ & $\begin{array}{l}\text { False } \\
\text { negative } \\
\text { rate }\end{array}$ \\
\hline $\begin{array}{l}\text { True } \\
\text { class 0 }\end{array}$ & $\begin{array}{l}14.4 \pm 1.1 \\
(22.5 \%)\end{array}$ & $\begin{array}{l}0.1 \pm 0.3 \\
(0.2 \%)\end{array}$ & $\begin{array}{l}0.2 \pm 0.6 \\
(0.3 \%)\end{array}$ & $\begin{array}{l}0.3 \pm 0.9 \\
(0.5 \%)\end{array}$ & 15 & $32.4 \%$ & $4.0 \%$ \\
\hline $\begin{array}{l}\text { True } \\
\text { class 2 }\end{array}$ & $\begin{array}{l}5.2 \pm 2.3 \\
(8.1 \%)\end{array}$ & $\begin{array}{l}9.1 \pm 2.6 \\
(14.2 \%)\end{array}$ & $\begin{array}{l}0.2 \pm 0.6 \\
(0.3 \%)\end{array}$ & $\begin{array}{l}0.5 \pm 0.7 \\
(0.8 \%)\end{array}$ & 15 & $1.2 \%$ & $39.3 \%$ \\
\hline $\begin{array}{l}\text { True } \\
\text { class 5 }\end{array}$ & $\begin{array}{l}3.9 \pm 1.2 \\
(6.1 \%)\end{array}$ & $\begin{array}{l}0.2 \pm 0.4 \\
(0.3 \%)\end{array}$ & $\begin{array}{l}0.3 \pm 0.9 \\
(0.5 \%)\end{array}$ & $\begin{array}{l}6.6 \pm 1.3 \\
(10.3 \%)\end{array}$ & 11 & $1.9 \%$ & $97.3 \%$ \\
\hline $\begin{array}{l}\text { True } \\
\text { class 6 }\end{array}$ & $\begin{array}{l}6.8 \pm 2.3 \\
(10.6 \%)\end{array}$ & $\begin{array}{l}0.3 \pm 0.5 \\
(0.5 \%)\end{array}$ & $\begin{array}{l}0.6 \pm 1.1 \\
(0.9 \%)\end{array}$ & $\begin{array}{l}15.3 \pm 2.3 \\
(23.9 \%)\end{array}$ & 23 & $18.0 \%$ & $33.5 \%$ \\
\hline Total & 30.3 & 9.7 & 1.3 & 22.7 & 64 & & \\
\hline
\end{tabular}

Table 21. Confusion matrix for classification on the Swerdlow scale of ischemic injury based on the FNN network and the measurement point at five hours of reperfusion, presented as the mean over $10 \mathrm{RDCV}$ runs \pm one standard deviation over the runs, and the percentage of total predictions within the class. The false positive and false negative rates are provided for each class (same row, column 1).

\begin{tabular}{|l|l|l|l|l|l|l|l|}
\hline $\mathrm{n}=64$ & $\begin{array}{l}\text { Predicted } \\
\text { class 0 }\end{array}$ & $\begin{array}{l}\text { Predicted } \\
\text { class 2 }\end{array}$ & $\begin{array}{l}\text { Predicted } \\
\text { class 5 }\end{array}$ & $\begin{array}{l}\text { Predicted } \\
\text { class 6 }\end{array}$ & Total & $\begin{array}{l}\text { False } \\
\text { positive } \\
\text { rate }\end{array}$ & $\begin{array}{l}\text { False } \\
\text { negative } \\
\text { rate }\end{array}$ \\
\hline $\begin{array}{l}\text { True } \\
\text { class 0 }\end{array}$ & $\begin{array}{l}13.8 \pm 1.0 \\
(21.6 \%)\end{array}$ & $\begin{array}{l}1.0 \pm 1.1 \\
(1.6 \%)\end{array}$ & $\begin{array}{l}0.2 \pm 0.6 \\
(0.3 \%)\end{array}$ & $\begin{array}{l}0.0 \pm 0.0 \\
(0.0 \%)\end{array}$ & 15 & $22.9 \%$ & $8.0 \%$ \\
\hline $\begin{array}{l}\text { True } \\
\text { class 2 }\end{array}$ & $\begin{array}{l}5.4 \pm 2.5 \\
(8.4 \%)\end{array}$ & $\begin{array}{l}8.7 \pm 2.4 \\
(13.6 \%)\end{array}$ & $\begin{array}{l}0.6 \pm 0.7 \\
(0.9 \%)\end{array}$ & $\begin{array}{l}0.3 \pm 0.7 \\
(0.5 \%)\end{array}$ & 15 & $6.9 \%$ & $42.0 \%$ \\
\hline
\end{tabular}




\begin{tabular}{|l|l|l|l|l|l|l|l|}
$\begin{array}{l}\text { True } \\
\text { class 5 }\end{array}$ & $\begin{array}{l}2.2 \pm 1.1 \\
(3.4 \%)\end{array}$ & $\begin{array}{l}1.8 \pm 0.6 \\
(2.8 \%)\end{array}$ & $\begin{array}{l}0.9 \pm 1.0 \\
(1.4 \%)\end{array}$ & $\begin{array}{l}6.1 \pm 1.4 \\
(9.5 \%)\end{array}$ & 11 & $5.1 \%$ & $91.8 \%$ \\
\hline $\begin{array}{l}\text { True } \\
\text { class 6 }\end{array}$ & $3.6 \pm 2.1$ & $\begin{array}{l}0.6 \pm 1.0 \\
(5.6 \%)\end{array}$ & $\begin{array}{l}1.9 \pm 1.1 \\
(3.0 \%)\end{array}$ & $\begin{array}{l}16.9 \pm 2.3 \\
(26.4 \%)\end{array}$ & 23 & $15.1 \%$ & $26.5 \%$ \\
\hline Total & 25.0 & 12.1 & 3.6 & 23.3 & 64 & & \\
\hline
\end{tabular}

